\title{
Comparative morphology of the mandibles of female polistine social wasps (Hymenoptera, Vespidae, Polistinae)
}

\author{
Orlando Tobias Silveira ${ }^{1} \&$ José Nazareno Araújo dos Santos Jr. ${ }^{1}$
}

1Coordenação de Zoologia, Museu Paraense Emílio Goeldi, Av. Perimetral 1901, 66077-830 Belém-PA, Brazil. orlando@museu-goeldi.br

\begin{abstract}
Comparative morphology of the mandibles of female polistine social wasps (Hymenoptera, Vespidae, Polistinae). Diversity of mandibular forms in female polistines is explored and compared among 116 species of all polistine genera. Inferences about function are made and discussed based on observed form differences. Mandible length and width measurements are analyzed for a subset of polistine species plus two vespines and two eumenines. A variable expressing the ratio between these variables is also considered in morphometric analyses. The following mechanical interactions among mandible structural elements are highlighted: opposition and crossing of mandibles' apical teeth at the middle of the closing trajectory; shearing action of the apical teeth against mesial denticles of the opposite mandible; shearing action of the mandible anterior margin against the ventral margin of the clypeus. In the genera Agelaia and Angiopolybia, exceptionally developed mesial mandibular structures may be related to necrophagy. In some epiponine genera, poorly developed mesial denticles and strong torsion of mandibles may be partially related to use of short wood fibers in nest construction as advanced by Sarmiento (2004). The considerable morphological variation found across the subfamily Polistinae is certain to be important in taxonomic and phylogenetic studies at the genus and species levels.
\end{abstract}

KEYWORDS. Adaptation; form-function analysis; morphometrics; phylogenetic methods; systematics.

RESUMO. Morfologia comparada da mandíbula da fêmea em vespas sociais da subfamília Polistinae (Hymenoptera, Vespidae). A diversidade morfológica da mandíbula da fêmea é explorada e comparada entre 116 espécies de todos os gêneros de Polistinae. Inferências sobre aspectos funcionais são feitas baseadas nas diferenças de forma observadas. Medidas do comprimento e largura da mandíbula, incluindo a razão entre essas variáveis, são analisadas para um subconjunto das espécies de Polistinae, mais duas de Vespinae e duas de Eumeninae. Os seguintes padrões de interação mecânica entre elementos estruturais são ressaltados: oposição e intercruzamento dos dentes apicais ao meio da trajetória de fechamento das mandíbulas; ação dilacerante dos dentes apicais contra os dentículos mesiais da mandíbula oposta; ação dilacerante da margem anterior da mandíbula contra a margem ventral do clípeo. Nos gêneros Agelaia e Angiopolybia, estruturas mesiais excepcionalmente desenvolvidas podem ser relacionadas ao hábito necrófago. Em alguns gêneros de Epiponini, o escasso desenvolvimento dos elementos mesiais e a forte torção do plano principal da mandíbula podem ser relacionados, pelo menos parcialmente, ao uso de fibras vegetais curtas na construção dos ninhos, como postulado por Sarmiento (2004). A considerável variação morfológica encontrada na subfamília Polistinae deverá prover informações importantes para análise em estudos taxonômicos e filogenéticos nos níveis de gênero e espécie.

PALAVRAS-CHAVE. Adaptação; análise de forma-função; métodos filogenéticos; morfometria; sistemática.

Adult female social wasps use their mandibles in various important contexts (Duncan 1939), such as for getting food (mostly arthropod prey) and feeding the larvae, in the collecting and application of materials used in nest construction (mainly wood fibers), in self and colonial defense, in social aggressive interactions, and in other more subtle and less known ways (see for example O'Donnell 2003). Some of these uses have been highlighted as traits of higher "salience" in the evolution of social behavior in vespid wasps (Hunt 1999), whose first appearance in a phylogeny is in close proximity to appearance of eusociality. Hunt mentions two such roles of mandibles in vespids: mandibular capture of larval provisions ("frees the sting from selection on provision anesthetization, and it opens a gateway to foraging efficiencies" [p. 231]), and malaxation of larval provisions ("provides the basic proteinaceous nourishment to support adult longevity accompanied by sustained synovigenic oogenesis at levels greater than those that can be achieved by solitary Aculeata" [p. 231]).
In spite of great importance in wasp biology and behavior, mandible morphology has received little attention either in studies of form-function correlation, or as source of characters for phylogenetic reconstruction. Morphological work has been done attempting to establish possible functional connections between the mandibular gland and "mandibular grooves" in Polistes species (Hermann et al. 1971; Singh \& Singh 1982), on the morphology of mandibular gland in Polistes fuscatus, with special attention to location of the gland opening and its functional consequences (Downing \& Jeanne 1982). Hansell (1987) studied morphometric aspects of female mandibles in some major vespid lineages as related to the mechanics involved in nest building and food preparation, regarded as facilitating factors in the evolution of eusociality. More recently, O'Donnell (1995) postulated the adaptive nature of mandibular features in the context of necrophagy observed in some epiponine species. Sarmiento (2004) extended the investigation of adaptive hypotheses in a study of correlations between mandibular traits and nest construction materials, and feeding 
habits, using well-formalized methods within a phylogenetic framework. With respect to studies on vespid phylogeny, Carpenter (1982) dismissed the value of mandible length as a character that could be used to recognize Eumeninae sensu Richards (1962) as a monophyletic group. More recently, Carpenter et al. (1996) discussed the relevance of mandible shape as evidence for a sister-group relationship between the genera Asteloeca and Metapolybia.

In this paper, diversity of mandibular forms in female polistines is explored and compared among the genera and species so as to produce a detailed survey of basic form elements, with a corresponding nomenclature. Inferences about function are also made and discussed based on observed form differences. The morphological data presented show that mandible form varies to some extent among polistine genera and species, in both qualitative and quantitative aspects. Some features may prove to be useful as characters in phylogenetic studies, and it is also expected that a morphologically wellfounded baseline may be of great value to comparative behavioral studies.

\section{MATERIAL AND METHODS}

One hundred and sixteen (116) species representing all polistine genera had their mandibles studied, in most cases being also figured and measured (see Appendix 1). Specimens were either collected for the study in the proximities of Belém (PA, Brazil) and Rio Claro (SP, Brazil), or selected from the collection of the Museu Goeldi. The species included in this study are mostly common and easily identifiable Neotropical social wasps. Ropalidiines were partly donated and identified by Dr. James Carpenter (AMNH) and Dr. Junichi Kojima (Ibaraki University). A few vespines and ropalidiines from the "Ducke Collection" at the Museu Goeldi have most probably been identified by R. Du Buysson. The most recent nomenclature referring to these taxa was adopted as in Carpenter \& Kojima (1997) and Kojima \& Carpenter (1997).

Mandible morphology was investigated either in the intact specimen or after dissection from the head. Dissected mandibles were observed under a binocular stereomicroscope (in alcohol within a Petri-dish filled partially with white sand), and drawings were made with a camera lucida. High magnification images of specimens were obtained with JEOL or ZEISS scanning electron microscopes. For SEM observations, alcohol-preserved mandibles were either dehydrated in critical point dryer or simply put to dry in room temperature, and after that coated with an ultrathin layer of gold in low vacuum sputter coating equipment.

Aspects of the movement of the mandibles relative to each other and to the head capsule were observed under the microscope through manipulation of recently killed specimens. Observations were also made on filmed individuals of labreared colonies of Mischocyttarus cerberus Ducke, to which various insect items were given as food.

Positional components of the names of mandibular parts as employed here take into account that polistine wasps are hypognathous insects, i.e. structures commonly said to be dorsal or ventral (as referring to drawings or images of dissected specimens; e.g. in O’Donnell 1995; or Sarmiento 2004) are here considered to be anterior or posterior, respectively. This is important when considering relations of mandibles to other structural elements of the head.

Morphometric data and analysis. Distance measurements of the mandible-length (from the posterior condyle to apex of the posteriormost apical "tooth 1"; Lmd) and basal mandiblewidth (Wmd) were taken on specimens under the stereomicroscope with an ocular micrometer. Head-width as estimated by interocular distance at the level of ocular sinus (Hdw), and height of the mesopleuron (from articulation of mid coxa to spiracular entrance; $\mathrm{Mph}$ ) were also measured for controlling of size or scale effects. One single set of measurements was taken for each of 94 species of 24 genera of Polistinae plus two vespines and two eumenines. Distance variables were logtransformed for conversion of exponential trends into linear ones, and to permit evaluation of allometry in bivariate relationships. A variable expressing the ratio $(\mathrm{R})$ between length and width of mandible was also considered in analyses.

Size correction was accomplished by using the residuals of ordinary least squares regressions (OLS) of variables on the mesopleuron-height (Mph), performed with the program Past 1.79 (Hammer et al. 2001). For the sake of comparison, "phylogenetic residuals" were also obtained with the phylogenetic generalized least squares (PGLS) procedure described by Revell (2009), with a code for the program MatLab ${ }^{\circledR}$ (The MathWorks Inc. 2006). For this analysis, a species phylogeny (Fig. 11) was assembled based on the genus level tree published by Wenzel \& Carpenter (1994), corrected for synonymies and extended to species level after Carpenter et al. (1996), Carpenter et al. (2000), Carpenter (2004), Pickett et al. (2006), Pickett \& Wenzel (2007), and Silveira (2008). Equal branch lengths arbitrarily assigned to one were employed in computation of phylogenetic distances used in the matrix "C" of interspecies covariance (see Revell 2009). We preferred not to use phylogenetic information from the most recent work on vespid phylogeny (Pickett \& Carpenter 2010), because this analysis was designed primarily to study higher level subfamily relationships, with some of the polistine genera being omitted.

For the study of characters' distributions and their correlations in a phylogenetic context, both quantitative and qualitative characters were coded into discrete states, and inspected for association with the functionality "Tree Mirror Window" in the software Mesquite 2.72 (Maddison \& Maddison 2009). The above mentioned species tree was pruned so as to reduce terminals to a number just sufficient to represent observed variation on qualitative characters in each clade (Fig. 15).

\section{RESULTS AND DISCUSSION}

Each of the mandibles of the female polistine wasp is a strongly reinforced appendage, articulated at two points to the lower lateral part of the head capsule (Fig. 1 D, F) (Duncan 
1939). It is relatively broad in cross-section at the base, the distal portion being more flattened and armed with four apical teeth, this number being constant across all the genera. Contrary to conditions found in some other insects such as grasshoppers, termites, and beetles (Chapman 1964, 1995), in the Polistinae the two mandibles are perfectly symmetrical. Because of the hinge-like dicondylic articulation, the movement of each mandible is restricted to one plane and, given that the anterior articulation is positioned slightly above and mesad relative to the posterior one, the mandibles overlap (or cross each other) along a slightly posteriorly oriented trajectory (see Snodgrass 1935).
Although the three-dimensional form (and corresponding functional properties) of the mandibles varies to some extent, a common basic plan of surfaces and landmarks can be recognized in every genus and species, this also being true with respect to sensory hairs. The following basic description of form elements is based on the species Polistes carnifex (Fabricius, 1775). While being representative of Polistes and several other genera as well, this basic pattern is taken here as reference for the reporting of aspects of form variation observed in all the studied taxa.

Mandible form in external view. The mandible of $P$. carnifex has a short aspect, being distinctly wide at the base,


Fig. 1. A-B: external and mesial view of the mandible in P. carnifex; C: detail of apical region of mandible and clypeus in P. carnifex; D: ventral aspect of head and mandibles in S. surinama; E: frontal view of clypeus and mandibles in B. scutellaris; F: posterior apical view of mandibles in B. scutellaris. 
with the ratio between total length (Lmd) and basal width (Wmd) around 2.0 (quite variable among polistine taxa; see Figs. 1 A, B; Tables I, II). Although not always clearly delimited by structural landmarks, several areas may be recognized on the mandible's surface whose topographic aspects vary among studied taxa. There is an external basal area (Fig. 1A, eba) extending from the basal margin (Fig. 1A, ebm) to a point situated about half-way the mandible's length. A convex distal posterior area (Fig. 1A, dpa) is continuous with the posteriormost apical tooth 1 (t1), and stays adjacent to a distal medial area (Fig. 1A, dma), which in this particular species (and genus) is gently convex, but that in other cases may be rather flattened and considerably oblique relative to the main plane of the mandible. Adjacent to the anterior margin (Fig. 2A, am), there is also a narrow anterior area (Fig. 2A, aa), which is relatively flattened and orthogonal to the main surface of the mandible. The apical teeth 1-3 have their apexes narrowly round or subacute, approximately perpendicularly aligned to the mandible's longitudinal axis, given that tooth 1 is both short and a little curved mesiad; tooth 3 has its anterior border much longer than the posterior one, developed into a very sinuous sharp edge, the gap separating this and subsequent anteriormost apical tooth $4(\mathrm{t} 4)$ being a relatively shallow notch (Fig. 2A). The apical tooth 4 has the apex narrowly round and moderately projecting, and its inward facing border has a long concave profile terminating in an acute and prominent anterior marginal angle (Fig. 2A, ang). The anterior margin is developed into a sharp darkened cutting border, with a distinctly concave profile. The posterior margin is composed of a basal portion (Fig. 1A, pmb), shaped as a blunt border, and of a sharp distal element (Fig. $1 \mathrm{~A}, \mathrm{~B}$, pde) that is continuous with the posterior border of the tooth 1. At about the middle of the posterior margin's length, the distal element inflects mesially and is then continuous with a round mesial oblique edge (Fig. 1B, ore) that extends up to the mandible's basal margin on the mesial side.

Mesial view. In mesial view, the oblique edge mentioned above is the limit between a roughly triangular mesial basal area (Fig. 1B, mba), located near the posterior condyle, and the larger (and concave) mesial distal area of the mandible (Fig. 1B, mda). The basal margin has a deep mesial emargination (Fig. 1B, me) near reception of the apodeme of the adductor muscle, and a narrow anterior loop (Fig. 1B, al) just contiguous to the anterior acetabular articulation of the mandible.

The mesial distal area has a distinct concave aspect, and presents a series of three subapical mesial denticles or crests (Fig. 1B). The anterior denticle is a prominent sharp edge that traverses the space between the anterior marginal angle and a point situated under the limits of apical tooth 3 (Fig. $1 \mathrm{~B}$, ar). In apical view, the anterior denticle has a curve trajectory near the point where it meets the anterior marginal angle. At this point, continuous with the anterior denticle is located the distal extremity of a moderately elevated but not sharp mesial anterior carina (Fig. 1B, mac) which runs alongside the anterior margin. The space between anterior margin

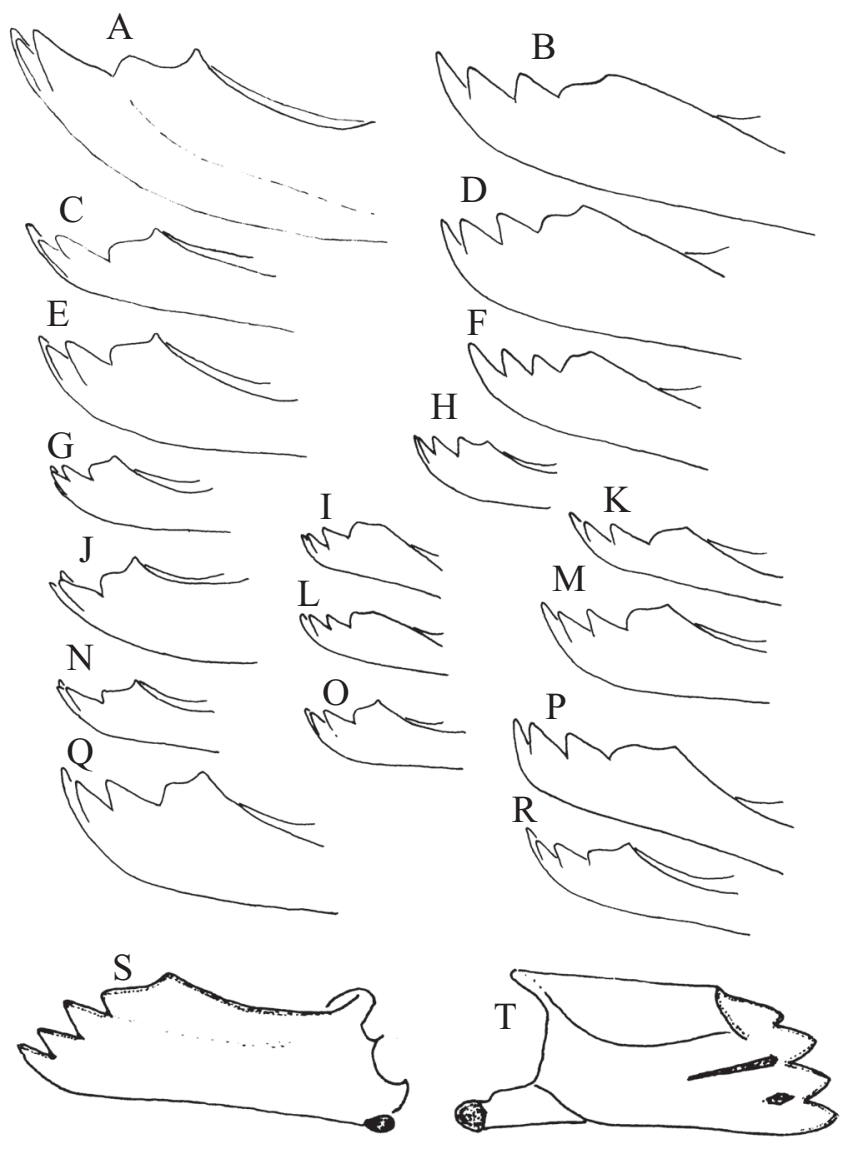

B

Fig. 2. A-R: Anterior apical view of mandible in A- P. carnifex; B- S. virginea; C-M. rotundicollis; D- E. tatua; E-A. pallens; F- B. bilineolata; G-A. pallipes; H- C. globiventris; I- P. chartergoides; K- C. apicepennis; L- P. sylveirae; MC. sulcata; N- P. fulgidipennis; O- M. cingulata; P- P. depressa; Q- A. traili; R- $P$. rejecta; $\mathrm{S}-\mathrm{T}$ : external and mesial views of mandible in $B$. juncea.

and mesial carina is developed into an elongate concavity or mesial anterior sulcus (Fig. 1B, sul). The median denticle is situated just between apical teeth 2 and 3 , and is produced as a long but not quite acute crest (Fig. 3, mr). The posterior denticle is located between teeth 1 and 2, and is lower and shorter than the median denticle, terminating quite abruptly at its distal extremity (Fig. 1B, pr).

Continuity between the distal element of the posterior margin and the mesal oblique edge is developed in extreme form in part of the Eumeninae (Zethus and Montezumia spp, but not in Zeta argillaceum), in which a high carina extends from the inner basal margin up to the posterior margin of the tooth 1 (Fig. 7G). The very salient form of the distal element of the posterior margin in these wasps is correlated with the development of a deep marginal sulcus, referred by authors as the "lateral mandibular groove" (Hermann et al. 1971; Singh \& Singh 1982). In the Polistinae such a groove is much less developed, associated with a row of marginal bristles. In Polistes carnifex the distal element of the posterior margin is practically parallel to the anterior margin, the basal portion of the margin diverging proximally according to a very low angle. 
Table I. Matrix with fourteen female mandibular characters for 53 species of 24 genera of Polistinae (see Table II for character state descriptions).

\begin{tabular}{|c|c|c|c|c|c|c|c|c|c|c|c|c|c|c|}
\hline Species/Character number & 1 & 2 & 3 & 4 & 5 & 6 & 7 & 8 & 9 & 10 & 11 & 12 & 13 & 14 \\
\hline Agelaia cajennensis & 0 & 0 & 0 & 0 & 0 & 1 & 0 & 3 & 1 & 0 & 0 & 0 & 0 & 0 \\
\hline Agelaia lobipleura & 1 & 1 & 0 & 0 & 0 & 1 & 0 & 3 & 1 & 0 & 0 & 0 & 0 & 0 \\
\hline Agelaia fulvofasciata & 1 & 1 & 1 & 0 & 0 & 1 & 0 & 3 & 1 & 0 & 0 & 0 & 1 & 0 \\
\hline Agelaia ornata & 0 & 0 & 0 & 0 & 0 & 1 & 0 & 3 & 1 & 0 & 0 & 0 & 0 & 0 \\
\hline Agelaia testacea & 0 & 0 & 0 & 0 & 0 & 1 & 0 & 3 & 1 & 0 & 0 & 0 & 0 & 0 \\
\hline Agelaia angulata & 0 & 0 & 0 & 0 & 0 & 1 & 0 & 3 & 1 & 0 & 0 & 0 & 0 & 0 \\
\hline Angiopolybia pallens & 0 & 0 & 0 & 0 & 0 & 1 & 0 & 3 & 1 & 0 & 0 & 0 & 0 & 0 \\
\hline Angiopolybia paraensis & 0 & 1 & 1 & 0 & 0 & 1 & 0 & 3 & 1 & 0 & 0 & 0 & 0 & 0 \\
\hline Chaterginus fulvus & 0 & 0 & 3 & 1 & 1 & 1 & 1 & 4 & 1 & 2 & 0 & 2 & 2 & 0 \\
\hline Protonectarina sylveirae & 0 & 0 & 1 & 1 & 1 & 1 & 1 & 4 & 1 & 2 & 0 & 1 & 1 & 0 \\
\hline Polybia dimidiata & 1 & 1 & 1 & 0 & 0 & 1 & 0 & 0 & 1 & 1 & 0 & 0 & 1 & 1 \\
\hline Polybia singularis & 0 & 0 & 0 & 0 & 0 & 1 & 0 & 0 & 1 & 1 & 0 & 0 & 1 & 3 \\
\hline Polybia occidentalis & 0 & 0 & 0 & 0 & 1 & 1 & 0 & 0 & 1 & 1 & 0 & 1 & 2 & 1 \\
\hline Polybia rejecta & 0 & 0 & 2 & 0 & 1 & 1 & 0 & 0 & 1 & 1 & 0 & 1 & 2 & 1 \\
\hline Polybia depressa & 0 & 0 & 0 & 0 & 2 & 1 & 3 & 5 & 2 & 1 & 0 & 2 & 1 & 1 \\
\hline Polybia striata & 0 & 0 & 0 & 0 & 1 & 1 & 3 & 0 & 1 & 4 & 0 & 1 & 2 & 1 \\
\hline Polybia jurinei & 0 & 0 & 2 & 0 & 1 & 1 & 0 & 0 & 1 & 1 & 0 & 1 & 1 & 1 \\
\hline Polybia ignobilis & 0 & 0 & 0 & 0 & 1 & 1 & 0 & 0 & 1 & 1 & 0 & 1 & 2 & 1 \\
\hline Epipona tatua & 1 & 0 & 0 & 2 & 2 & 1 & 2 & 5 & 2 & 4 & 1 & 3 & 1 & 1 \\
\hline Chartergus metanotalis & 1 & 0 & 0 & 0 & 1 & 1 & 0 & 1 & 1 & 0 & 0 & 1 & 1 & 0 \\
\hline Brachygastra bilineolata & 0 & 0 & 2 & 2 & 2 & 1 & 2 & 5 & 2 & 4 & 0 & 3 & 1 & $?$ \\
\hline Asteloeca traili & 1 & 1 & 0 & 0 & 1 & 1 & 0 & 0 & 1 & 1 & 0 & 1 & 1 & 1 \\
\hline Metapolybia cingulata & 1 & 1 & 1 & 0 & 1 & 1 & 0 & 0 & 1 & 1 & 0 & 1 & 1 & 1 \\
\hline Metapolybia rufata & 1 & 1 & 3 & 0 & 1 & 1 & 0 & 0 & 1 & 1 & 0 & 1 & 1 & 1 \\
\hline Clypearia sulcata & 0 & 0 & 2 & 0 & 2 & 1 & 0 & 0 & 1 & 1 & 0 & 2 & 2 & 1 \\
\hline Clypearia weyrauchi & 0 & 0 & 2 & 0 & 2 & 1 & 3 & 4 & 1 & 4 & 0 & 3 & 3 & 1 \\
\hline Clypearia apicepennis & 0 & 0 & 2 & 1 & 2 & 1 & 3 & 5 & 1 & 4 & 0 & 3 & 2 & 1 \\
\hline Synoeca surinama & 0 & 0 & 2 & 2 & 2 & 1 & 2 & 5 & 2 & 4 & 1 & 3 & 1 & 1 \\
\hline Protopolybia chartergoides & 0 & 0 & 3 & 1 & 1 & 1 & 1 & 4 & 1 & 2 & 0 & 2 & 3 & 0 \\
\hline Protopolybia emortualis & 0 & 0 & 2 & 1 & 2 & 1 & 1 & 4 & 2 & 4 & 0 & 3 & 0 & 0 \\
\hline Protopolybia sedula & 0 & 0 & 3 & 1 & 1 & 1 & 1 & 4 & 1 & 2 & 0 & 2 & 3 & 0 \\
\hline Leipomeles dorsata & 0 & 1 & 1 & 0 & 0 & 1 & 0 & 0 & 1 & 0 & 0 & 0 & 0 & $?$ \\
\hline Chartergellus nigerrimus & 1 & 0 & 0 & 0 & 1 & 1 & 0 & 0 & 3 & 3 & 0 & 1 & 1 & 0 \\
\hline Parachartergus lenkoi & 1 & 1 & 1 & 0 & 0 & 1 & 0 & 0 & 1 & 0 & 0 & 0 & 0 & 0 \\
\hline Parachartergus fraternus & 1 & 1 & 1 & 0 & 0 & 1 & 0 & 0 & 1 & 0 & 0 & 0 & 0 & 0 \\
\hline Pseudopolybia langi & 1 & 1 & 0 & 0 & 0 & 1 & 0 & 0 & 1 & 0 & 0 & 0 & 0 & $?$ \\
\hline Pseudopolybia vespiceps & 1 & 1 & 1 & 0 & 0 & 1 & 0 & 0 & 1 & 0 & 0 & 0 & 0 & 0 \\
\hline Apoica arbórea & 1 & 0 & 2 & 0 & 1 & 1 & 0 & 0 & 1 & 0 & 0 & 1 & 1 & $?$ \\
\hline Apoica pallida & 1 & 0 & 1 & 0 & 0 & 1 & 0 & 2 & 1 & 0 & 0 & 0 & 1 & 2 \\
\hline Parapolybia indica & 0 & 1 & 0 & 0 & 0 & 1 & 0 & 2 & 0 & 0 & 0 & 0 & 0 & 0 \\
\hline Ropalidia pracina & 0 & 0 & 1 & $?$ & 0 & 1 & $?$ & $?$ & $?$ & 0 & $?$ & 0 & 0 & 1 \\
\hline Ropalidia guttatipennis & 0 & 0 & 1 & 0 & 0 & 1 & 0 & 4 & 2 & 4 & 0 & 0 & 1 & 1 \\
\hline Ropalidia hornii & 0 & 0 & 1 & 0 & 0 & 1 & 0 & 0 & 0 & 0 & 0 & 0 & 0 & 1 \\
\hline Polybioides melainus & 0 & 0 & 1 & 0 & 0 & 1 & 0 & 2 & 0 & 0 & 0 & 0 & 1 & 0 \\
\hline Belonogaster sp & 0 & 0 & 0 & 0 & 0 & 1 & 0 & 6 & 0 & 0 & 1 & 1 & 0 & 0 \\
\hline Mischocyttarus montei & 0 & 0 & 2 & 0 & 0 & 1 & 0 & 1 & 1 & 0 & 0 & 1 & 1 & 1 \\
\hline Mischocyttarus synoecus & 0 & 1 & 0 & 0 & 0 & 1 & 0 & 1 & 1 & 0 & 0 & 1 & 0 & 1 \\
\hline Mischocyttarus collarellus & 0 & 1 & 0 & 0 & 0 & 1 & 0 & 1 & 1 & 0 & 0 & 1 & 0 & 1 \\
\hline Mischocyttarus punctatus & 0 & 0 & 0 & 0 & 0 & 1 & 0 & 1 & 1 & 0 & 0 & 1 & 0 & 1 \\
\hline Mischocyttarus rotundicollis & 0 & 0 & 2 & 0 & 0 & 1 & 0 & 1 & 1 & 0 & 0 & 1 & 0 & 1 \\
\hline Mischocyttarus flavicans & 0 & 1 & 0 & 0 & 0 & 1 & 0 & 1 & 1 & 0 & 0 & 1 & 1 & 1 \\
\hline Polistes carnifex & 0 & 0 & 0 & 0 & 0 & 0 & 0 & 0 & 0 & 0 & 0 & 0 & 0 & 0 \\
\hline Polistes pacificus & 0 & 0 & 0 & 0 & 0 & 1 & 0 & 0 & 0 & 0 & 1 & 0 & 0 & 0 \\
\hline
\end{tabular}


Table II. Description of the character states.

Description of mandible character states-for inference of ancestral conditions in phylogeny of Figure 15, parsimony optimization of characters $3,7,8$, 910 , and 14 assumes unordered transformations among states.

1) Form of external basal area: (0) just plane or gently convex, integument with normal texture, with conspicuous hairs; (1) with a flattened or depressed roughly triangular area presenting a smooth, often pale aspect, nearly glabrous.

2) Proximal part of posterior margin: (0) as a blunt or moderately acute border; (1) strongly compressed, lamellate.

3) Profile shape of posterior margin: (0) margin roughly straight; (1) proximal and distal elements forming a distinct angle; (2) margin with a gentle curve;

(3) with a remarkably sinuous profile.

4) Profile shape of anterior margin: (0) margin curved, sharp and darkened throughout; (1) margin nearly straight, sharp; (2) margin straight, reduced at the base, not really sharp.

5) Shape of apical teeth 1-2: (0) teeth 1-2 similarly shaped and sized, rather short; (1) tooth 1 just longer than tooth 2; (2) tooth 1 distinctly longer than tooth 2 , and considerably wider.

6) Shape of apical tooth 3: (0) with anterior border much longer and sinuous; (1) anterior border as long as the posterior one.

7) Shape of tooth 4: (0) apex either roundly or more acutely pointed, marginal angle prominent; (1) whole tooth strongly projecting, marginal angle obtuse or absent; (2) apex strongly reduced, marginal angle obtuse; (3) apex undefined, not projecting, tooth contour as a low arch, marginal angle obtuse. UNORDERED

8) Form of mesial anterior carina and anterior denticle: (0) carina low, roundly produced, its distal extremity converging towards the outer element of the mesial anterior denticle at a point close to the marginal angle; (1) carina low, positioned obliquely relative to the anterior margin so that the adjacent mesial sulcus is almost obliterated, carina's distal extremity distinctly separated from the marginal angle; (2) carina sharp in its distal extremity, running parallel to the anterior margin, encountering the mesial anterior denticle at a point reasonably distanced from the marginal angle; (3) carina sharp for most of its length, widely separated and parallel to the anterior margin, carina's distal extremity forming with the outer element of the mesial anterior denticle a very prominent molar structure; (4) carina reduced, rather obliquely positioned, just traceable alongside the associated row of bristles, yet the mesial anterior denticle sharply developed; (5) both carina and mesial anterior denticle strongly reduced, carina oblique and straight; (6) carina and anterior denticle reduced, carina's traceable trajectory forming a wide inward displaced curve. UNORDERED

9) Shape of mesial median denticle: (0) a linear elongated crest whose distal extremity terminates abruptly, or even as a pointing end that projects distally; (1) a roughly triangular and moderately elongated crest, with distal extremity shaped as an oblique gradually sloping sharp edge; (2) greatly reduced, mainly transversal, with rather blurred edges; (3) normally raised as in state 1, but displaced to the midline of tooth 3. UNORDERED

10) Shape of mesial posterior denticle: (0) linear, variably elongated and elevated, with distal extremity abrupt or pointing distally, located between teeth 1 and 2; (1) a roughly triangular and moderately elongated crest, with distal extremity shaped as gradually sloping sharp edge; (2) a very short and salient triangular crest; (3) a roughly triangular crest as in state 1 , but displaced to midline of tooth 2 . UNORDERED

11) Length of hairs on external surface: (0) long; (1) short.

12) Degree of torsion of apical region of the mandible: (0) without significant torsion of external distal medial area, in frontal view tooth 1 appearing partially hidden beneath tooth 2; (1) in frontal view, tooth 1 just visible, distal area subjacent to tooth 3 standing out obliquely; (2) in frontal view, teeth 1-3 well separated from each other, distal area subjacent to teeth $2-4$ standing out obliquely; (3) whole distal area subjacent to teeth $1-4$ appearing as a nearly vertical plane in frontal view.

13) Ratio between length and width of the mandible: (0) $1.8-2.2$; (1) $2.3-2.7$; (2) $2.8-3.3$; (3) $3.4-3.8$. (state ranges are arbitrarily set to 0.4 , with a minor adjustment with respect to the upper limit of state 2).

14) Nest construction material: (0) long fiber; (1) short fiber; (2) plant hairs; (3) with mud addition. UNORDERED

Sensory hairs. Conspicuous hairs of various lengths are distributed on the external surface of the mandible, sometimes arranged in rows, as in the case of hairs along the distal element of the posterior margin (Fig. 1A). On the anterior area, near the mandible base, there is a dense group of very short hairs, the basal "brush of bristles" (sensu Downing \& Jeanne 1982) (Fig. 1A, bb). On the mesial surface, beside the anterior denticle and continuing along the mesial anterior carina there is a row of rather long hairs. A shorter row of hairs also occurs beside the median denticle. Short inconspicuous hairs may occur on the mesial basal area (Fig. 1B).

Variation within the genus Polistes. All examined species of the genus presented mandibles very similar to the above described (see also Fig. 4A). In some species, however, the anterior border of tooth 3 is not so elongated as in $P$. carnifex and other species of the groups of $P$. canadensis and $P$. versicolor. All observed species of the former subgenus Epicnemius Richards (see Carpenter 1996 for current sub- genus level classification) presented only hairs of a much shorter type on the mandible's external surface than those hairs found in species of other examined groups.

The ropalidiine genera (Parapolybia, Ropalidia, Belonogaster, and Polybioides). In the examined ropalidiine species, the mandible presents the same general form observed in Polistes. In most of the observed Ropalidia, the mandible tends to be relatively short and more distinctly wider at the base than at the apex, a shallow angle existing between the basal and distal portions of the posterior margin. Tooth 1 is generally rather short and a somewhat divergent relative to tooth 2 , as if pointing backwards. Tooth 3 is shaped more like an isosceles triangle, with the anterior border shorter than in $P$. carnifex, and its apex is in a more retracted position compared to that reached by the apex of tooth 1 . In some species, the tooth 3 is distinctly narrower as in $R$. grandidier $i$ (de Saussure, 1890), R. fasciata (Fabricius, 1804), R. horni Sonan 1938, and $R$. cincta (Lepeletier, 1836). In a large spe- 


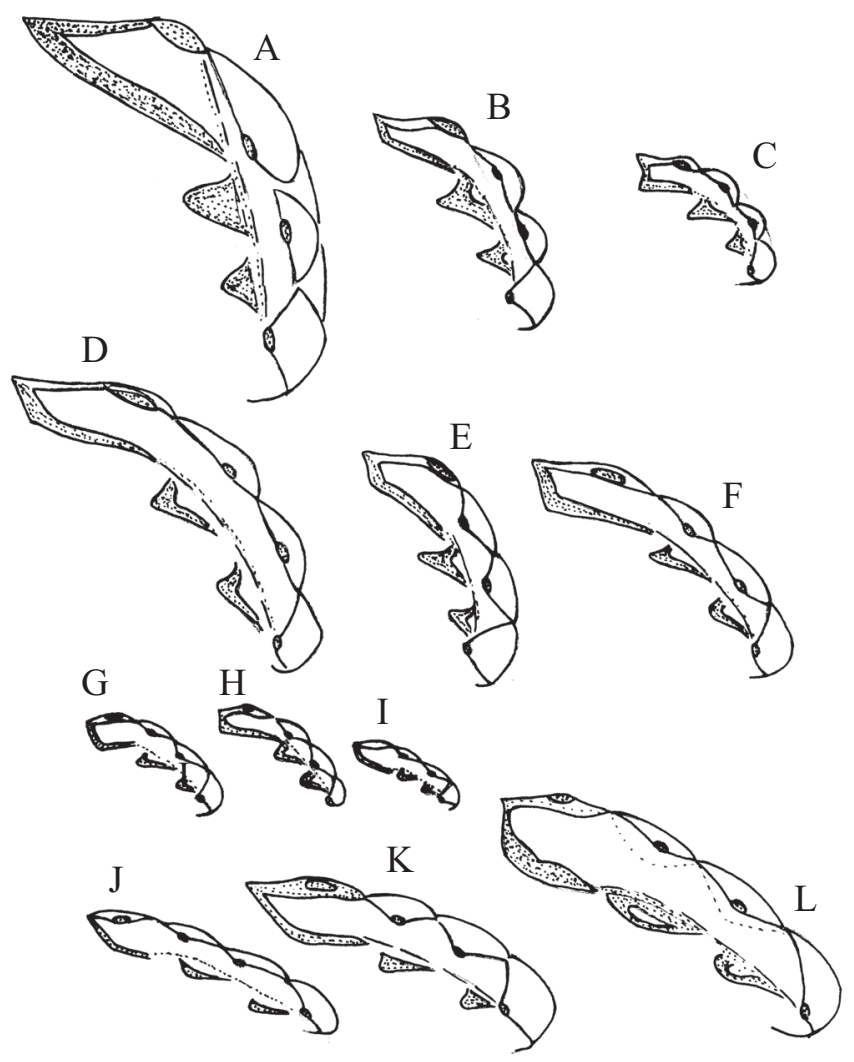

Fig. 3. Apical view of mandible in: A- P. carnifex; B- A. pallens; C- A. cajennensis; D- P. dimidiata; E- P. ignobilis; F- P. liliacea; G- P. sylveirae; H- C. fulvus; I- P. chartergoides; J- B. bilineolata; K- E. tatua; L- S. virginea.

cies like $R$. prasina (de Saussure, 1900), however, apical teeth are very robust, and tooth 1 and adjacent marginal region appear as if twisted and pulled backwards. A more radical shape modification was observed in a species of the $R$. malayana-complex (Malaysia, Cap. Naga Sahari, Pulau Tioman, Pahang; Bohart Museum) in which most of the apical region is strongly twisted up and backwards, and the apical teeth align with each other forming a cutting edge that is nearly orthogonal to the main plane of the mandible. Dr. J. Kojima (in litt.) states that this kind of mandible shape is also observed in the R. pilosa and R. lefebvrei groups. Interestingly, quite similar forms occur in Neotropical genera like Brachygastra, Protopolybia and Synoeca (see below and Fig. $1 \mathrm{D}, \mathrm{E})$.

In Parapolybia indica (de Saussure, 1854), a remarkable feature of the mandible is the sharper mesial anterior carina that meets the mesial anterior denticle at a more centrally removed point relative to the anterior margin than in Polistes (Fig. 4C). An unidentified species of Polybioides presented a similar condition (Malaysia, Frasers Hill, Pahang; Bohart Museum).

In Belonogaster juncea (Fabricius, 1781) and another unidentified species of this genus (Senegal, Dakar, G. Melou 1905; Museu Goeldi) the mandible is more slender (about 2.4 times longer than wide at the base), with parallel anterior and posterior margins (Fig. $2 \mathrm{~S}, \mathrm{~T}$ ). Apexes of teeth 1-3 are aligned obliquely relative to the mandible's base. Tooth 3 is shaped as an isosceles triangle, and tooth 4 has the apex less prominent and with a long and concave anterior border terminating in a prominent anterior marginal angle. In mesial view, the salient features are the short and narrow mesial basal area, and the form and position of the mesial anterior carina (Fig. 2T). In Belonogaster this carina is poorly developed, with a markedly curved trajectory far removed from the anterior margin, and terminating at the distal extremity of the mesial anterior denticle (Fig. 2T), not at the proximal extremity as in all other polistine species. The space between the carina and the anterior margin forms a smoothly convex surface, so that a "mesial anterior sulcus" is not actually developed. Finally, in Belonogaster the bristles on the mandible's external surface are fewer and very short as in species of former subgenus Epicnemius of Polistes.

Mischocyttarus. In this genus, the mandible has often a robust shape in external view, with straight parallel anterior and posterior borders (Figs. 4 E, F), but exceptions can be seen in some groups like subgenus Monogynoecus, where the posterior margin may have a distinctly concave profile. Teeth 1 and 2 are larger than in Polistes, with their apices aligned obliquely relative to mandible's base. The ratio between mandible length and basal width varies around 2.2 (Tables I, II). Tooth 4 tends to be more prominent, and the anterior margin of the mandible is concave as in Polistes and most other polistines (Fig. 2C). The basal element of the posterior margin may be compressed and developed into a thin transparent lamellar border. The mesial emargination is most often shallow. The mesial anterior carina is distally welldeveloped, but it is positioned obliquely relative to the anterior margin, so that the mesial anterior sulcus appears as if obliterated and contorted outwards. The region where the mesial anterior denticle and carina meet is produced angularly, with a rather sharp edge extending basally for a short distance (Figs. 4 E, F). The mesial median denticle is shorter than in Polistes, appearing roughly as an elongated triangle with acute edges (compare to Figs. 1B, 4A).

The basal epiponine genera (Apoica, Agelaia, and Angiopolybia). In the genus Apoica, mandibles tend to be moderately slender (ratio between length and basal width around 2.4), and considerable differences exist between $A$. arborea de Saussure 1854 on the one hand and remaining species such as $A$. pallida (Olivier, 1791) and $A$. thoracica du Buysson 1906 (see Figs. 4 B, D). The external basal area is distinctly flattened with a smooth glabrous appearance in all examined species, but the size of the flattened area is much larger in A. arborea. Furthermore, in the latter species, tooth 1 (and whole distal posterior area) is strongly contorted backwards, giving the posterior margin a very distinctly curved profile. In frontal view, the narrow distal medial area (plus teeth $2-3$ ) seems rotated to a more oblique position relative to the main plane of the mandible. In mesial view, the largest differences are depth of mesial emargination, this being very shallow in A. arborea, and form of the distal portion of the mesial anterior carina (plus anterior denticle), which is blunt 

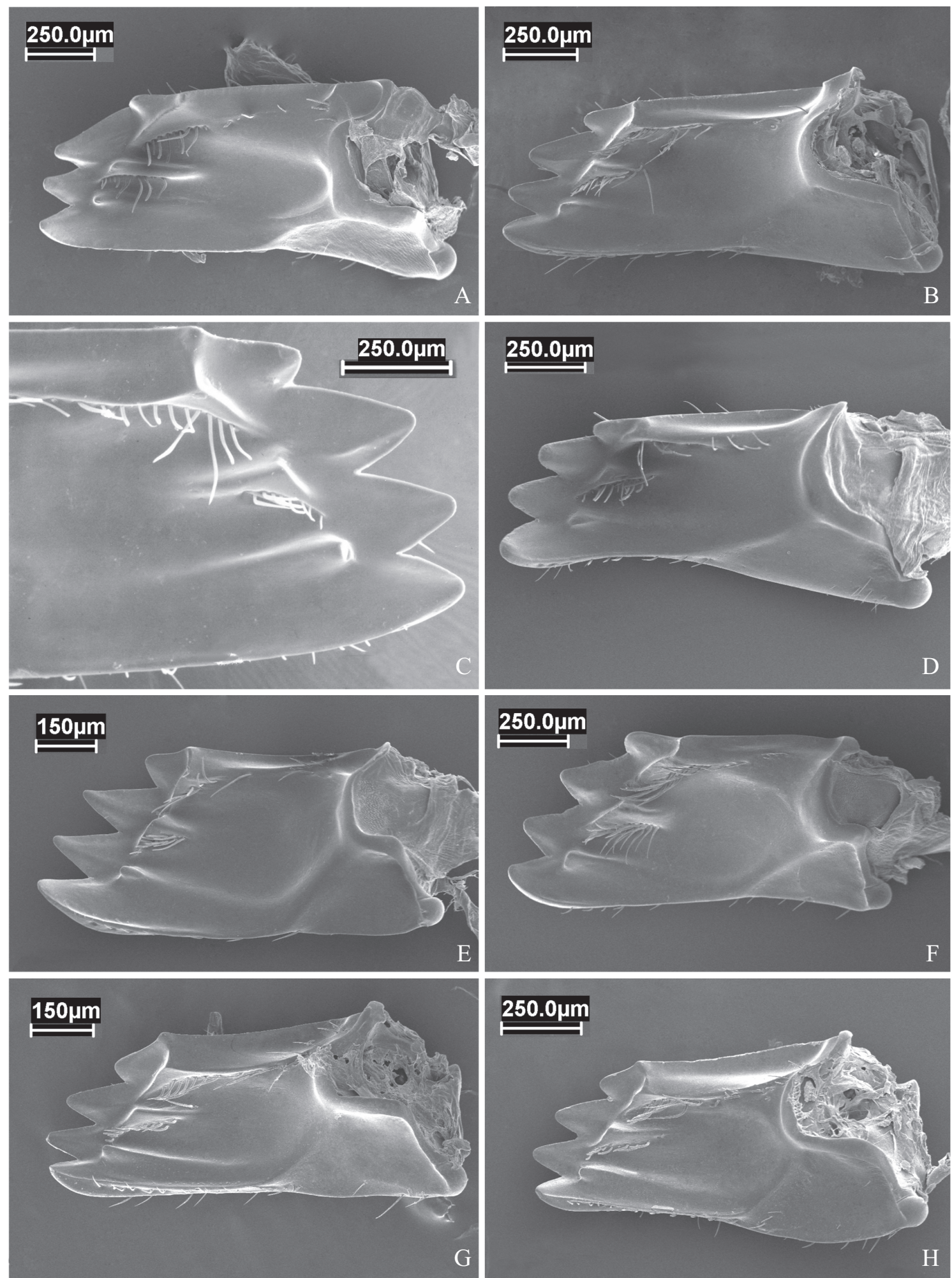

Fig. 4. Mesal view of mandible in: A- P. versicolor; B- A. pallida; C- P. indica; D. A. arborea; E- M. cerberus; F- M. drewseni; G- A. myrmecophila; H- A. fulvofasciata.

and very close to anterior margin in the latter species, while being sharp and more detached from the margin in A. pallida and other species.

Species of Agelaia and Angiopolybia have similar quite robust mandibles (ratio between length and basal width around 2.2), often with the posterior margin being slightly convergent to the apex as seen in lateral external view. Tooth 2 is distinctly more developed than in Polistes, and apices of teeth $1-2$ tend to be perpendicularly aligned relative to the mandible's base, being distanced further from the base than 
the apex of tooth 3 (Figs. 4 E, F and 5 A, B). Tooth 1 is often divergent, directed slightly backwards. In mesial view, a very distinctive feature of these two genera is the great development of both the anterior denticle (especially of its outer element) and the mesial anterior carina, the latter being unusually elevated and sharp, and in a more detached position from the anterior margin, with the corresponding formation of a very wide mesial anterior sulcus. These elements undoubtedly form together a prominent molar structure in these wasp species (Figs. 4 E, F and 5 A, B).

The Pseudopolybia-Nectarinella epiponine clade. In external view, aspects to be highlighted in these genera are the very short and stout aspect of the mandibles (ratio between length and basal width about 2.1), and the largely flattened and smooth aspect of the external basal area in most of them. The apical teeth are similar in Pseudopolybia to forms observed in Agelaia and Angiopolybia. However, in Parachartergus, Leipomeles and Nectarinella tooth 2 is comparatively smaller, being more similar to a condition found in Polistes. In mesial view, the anterior denticle and mesial anterior carina do not show the same level of development observed in Agelaia, being instead more similar to Polistes species or Apoica arborea (Figs. 5 C, D). Locations of the mesial posterior and median denticles in the genus Chartergellus are very peculiar, displaced to positions relatively closer to the anterior margin, and aligned with the midline of teeth 2 and midline of 3 respectively (not between apical teeth 1 and 2, and 2 and 3 , as in all other polistines). In larger species of Pseudopolybia, the distal element of the posterior margin is sharper and more sclerotized.

The Protopolybia-Clypearia epiponine clade. Species of Polybia (sensu Carpenter et al. 2000) tend to present variably slender, elongated mandibles (ratio between length and basal width varying from 2.2 up to 3.2 in P. striata (Fabricius, 1787) (see Figs. 5 E-H and 6 A-B). In frontal view, longer mandibles also tend to show the external distal medial area rotated to a variable degree (Figs. 3 D-F). Another characteristic of some Polybia is the relatively lower profile of tooth 4 , its contour produced as a more regular arch (Fig. 2P). In mesial view, elongation and torsion of the distal part of the mandible lead to a shallower (or nonexistent) mesial concavity. Apart from features related to elongation, however, mesial views of the mandible in Polybia species show many of the conditions observed in Polistes, such as a low and obtuse mesial anterior carina. The former genus Synoecoides Ducke (synonymized with Polybia by Carpenter et al. 2000) presents the characteristics of greater length and distal torsion of the mandible, showing in addition considerable attenuation of mesial denticles and anterior carina (Fig. 6B). Tooth 1 is very wide, and tooth 4 presents a low regular profile (Figs. $2 \mathrm{P}$ and $6 \mathrm{~B}$ ). The anterior margin seems a little less concave, with a rather blunt edge, different from other Polybia.

In the astelocyttarous-nest clade, the genera Asteloeca, Metapolybia and Clypearia display together a similar range of forms (Figs. $2 \mathrm{~K}, \mathrm{M}, \mathrm{O}, \mathrm{Q}$, and $7 \mathrm{~A}-\mathrm{D}$ ) as observed in Polybia (ratio between length and basal width varying from
2.2 up to 3.4 in C. weyrauchi Richards 1978), with elongation and torsion of the mandible being associated to alterations in form of mesial denticles and anterior carina. However, in Clypearia and Synoeca such trends are taken to extreme conditions, so that in frontal view, the apical teeth and distal medial area form a strongly oblique surface, almost coplanar with the mandible's closing trajectory (Fig. 1D). Associated with this, the mesial denticles and anterior carina tend to be very low, nearly fading structures (Fig. 7F). Other distinctive features observed in Synoeca species are: extreme reduction of tooth 4 (Figs. 2B and 7F); straight and blunt form of the anterior margin; great basal reinforcement of the mandible (very wide basally); shallow mesial emargination; and presence of a conspicuous moderately deep concavity located on the mesial basal area. Most of these characters are observed in similar states in the genera Epipona (Figs. 2D and 7E) (which has been considered as the sister group of the astelocyttarous-nest clade by Carpenter 1991 and more recently Picket \& Carpenter 2010, but see also Wenzel and Carpenter 1994, and Carpenter et al. 2000), and in Brachygastra (Figs. 2F and 6D) which is not closely related to these genera, but is instead sister group of Chartergus, which presents otherwise a more normal mandible similar to Polybia species (Figs. 2H and 6C). Epipona and Synoeca also share a shorter kind of hairs on the external surface of the mandible, much like those observed in Polistes (Epicnemius) and Belonogaster species.

Protopolybia species typically have slender mandibles (ratio between length and basal width varying from 2.6 in $P$. exigua up to 3.7 in $P$. fuscatus), with very distinctive forms (Figs. $2 \mathrm{~J}$ and $6 \mathrm{E}, \mathrm{F}$ ). The posterior margin is remarkably sinuous, ending in an enlarged and strongly projecting tooth 1 . The tooth 4 is a comparatively large projecting piece, and the mandible's anterior margin is straight and blunt basally. In mesial view, posterior and median denticles are usually very short and rather abruptly raised, but the anterior denticle and carina are poorly developed. Torsion of the apical area of the mandible is also a prominent feature in the genus (Fig. 3I), especially in the group of more stout species (Richards's picteti group), like P. emortualis (de Saussure, 1855 ) and $P$. nitida (Ducke, 1904).

Most species of the genus Charterginus have the mandibles (Figs. $3 \mathrm{H}$ and $6 \mathrm{H}$ ) practically identical to those of Protopolybia species like P. chartergoides (Gribodo, 1891) and $P$. sedula (de Saussure, 1854). However, in C. weyrauchi (Peru, Huanuco; types, NHM) the mandible presents a more planar aspect, with the posterior margin less sinuous. Protonectarina sylveirae (de Saussure, 1854) is rather similar to these taxa, but in it the mandible has a more robust aspect (Fig. 6E), the posterior margin being just straight, and the tooth 4 is not so strongly projecting (Fig. 2L).

Morphometric analysis. The adopted procedure of studying two distance measurements can only give us a partial understanding on the form complexity of the polistine mandible, but it may be justified in a first approach to the problem. Length and width measurements describe form 

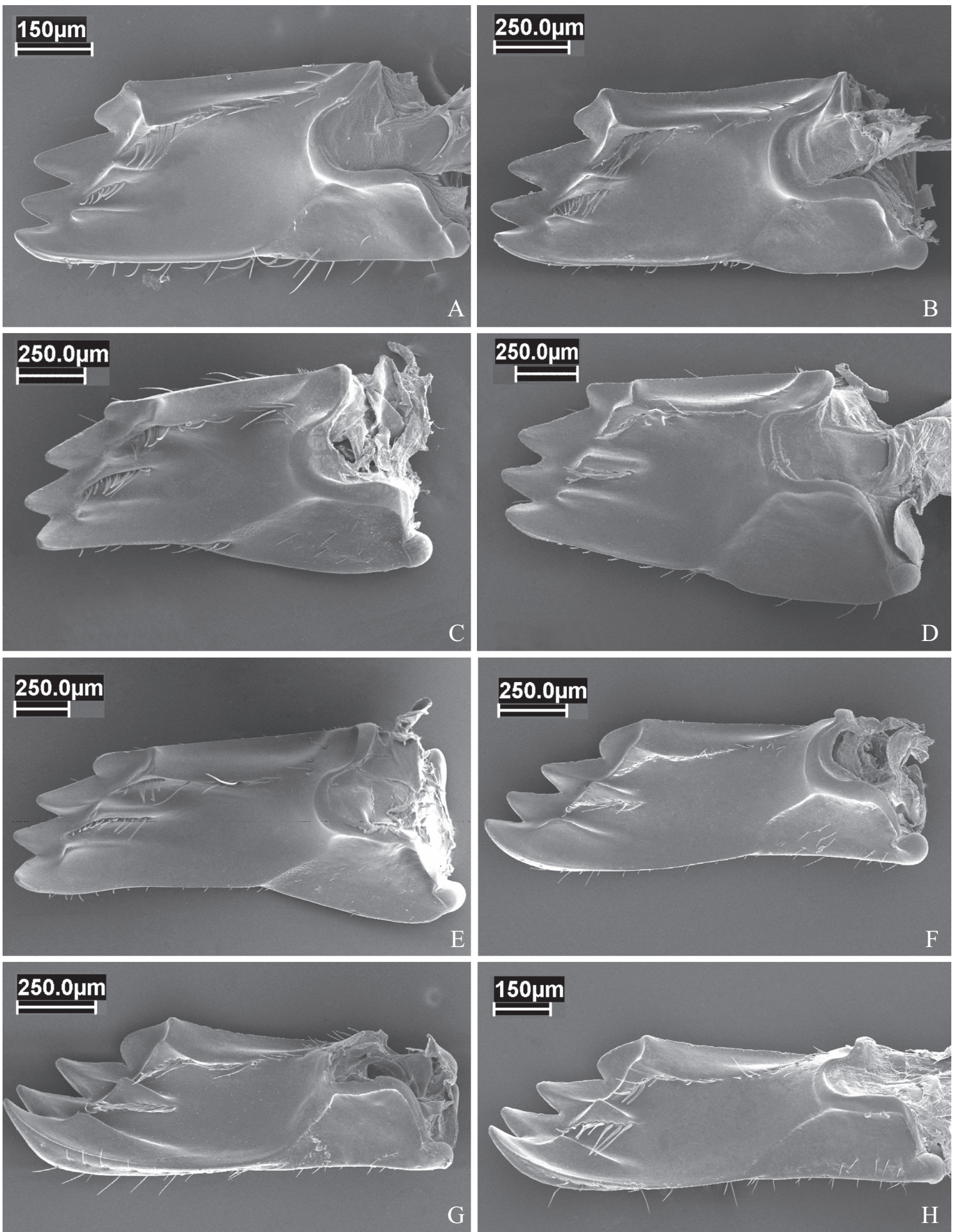

$150 \mu m$

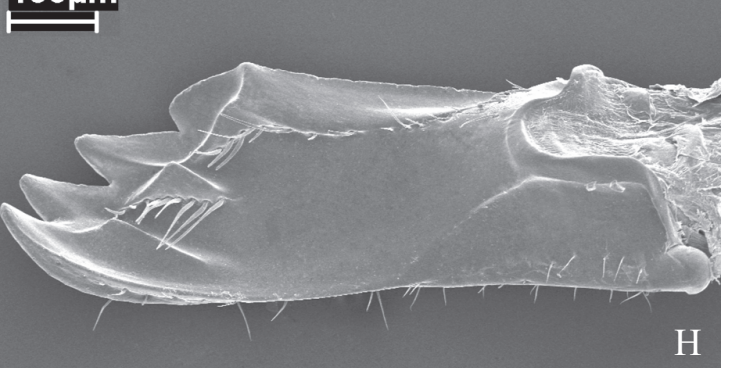

Fig. 5. Mesal view of mandible in: A- An. pallens; B- An. paraensis; C- P. vespiceps; D- P. fraternus; E- P. dimidiata; F- P. liliacea; G- P. jurinei; H- P. rejecta.

dimensions that are informative of mandible's major mechanical properties, considered as a first class lever system, and in addition can be easily obtained under the stereomicroscope. Information on such form descriptors may be thus of great interest, especially if studied in integrated manner with other characters, and with adequate methods.
Size variation normally occurring in interspecific morphometric datasets is an impediment to direct comparison of measurements between taxa. In the present case, differences in body size as large as those between Synoeca (ca. $20 \mathrm{~mm}$ body length) and Protopolybia species (ca. $5 \mathrm{~mm}$ ) require that an element of size correction be introduced into the analy- 
sis. This is accomplished here by regressing the variables of interest on a "size variable", and then using the residuals as size-corrected variables. In a previous study of interspecific data in polistine wasps (40 species of all Neotropical genera, except Nectarinella), Silveira \& Silveira (1994) have shown that the variable of height of the mesopleuron (Mph) has large correlation, and is nearly isometric with body size conceived as a general factor (e.g., the first principal component of a covariance matrix of log-transformed distance measurements). Mph is thus preferred here over measurements like the length of the anterior wing, a frequently used size surrogate in wasp studies which nonetheless shows high allometry with respect to other body dimensions (Silveira \& Silveira 1994). Interspecific allometry of wing linear dimen-
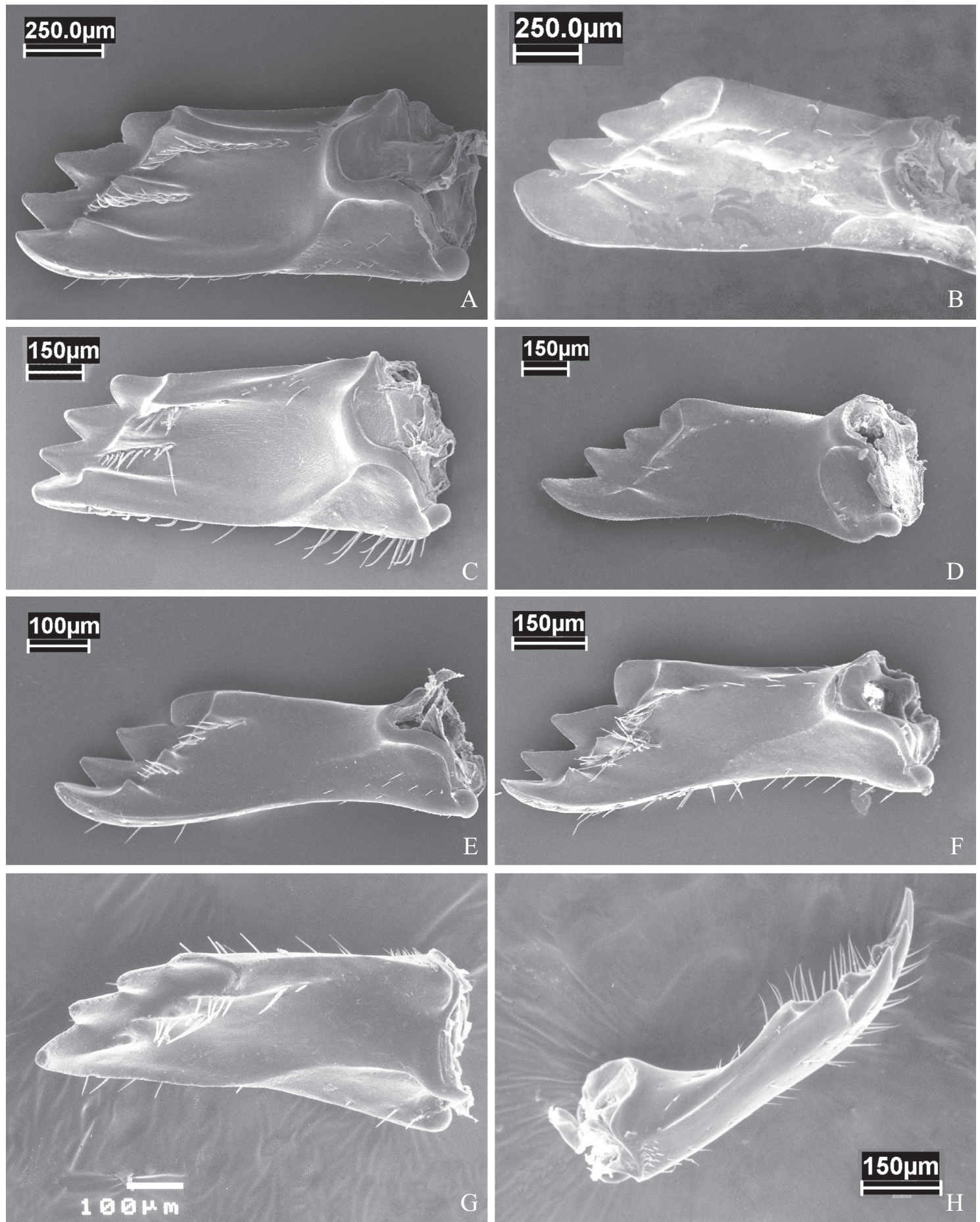

Fig. 6. Mesal view of mandible in: A- P. sericea; B- P. depressa; C- C. globiventris; D. B. bilineolata; E- P. sedula; F- P. chartergoides; G- P. sylveirae; HC. fulvus (anterior view). 

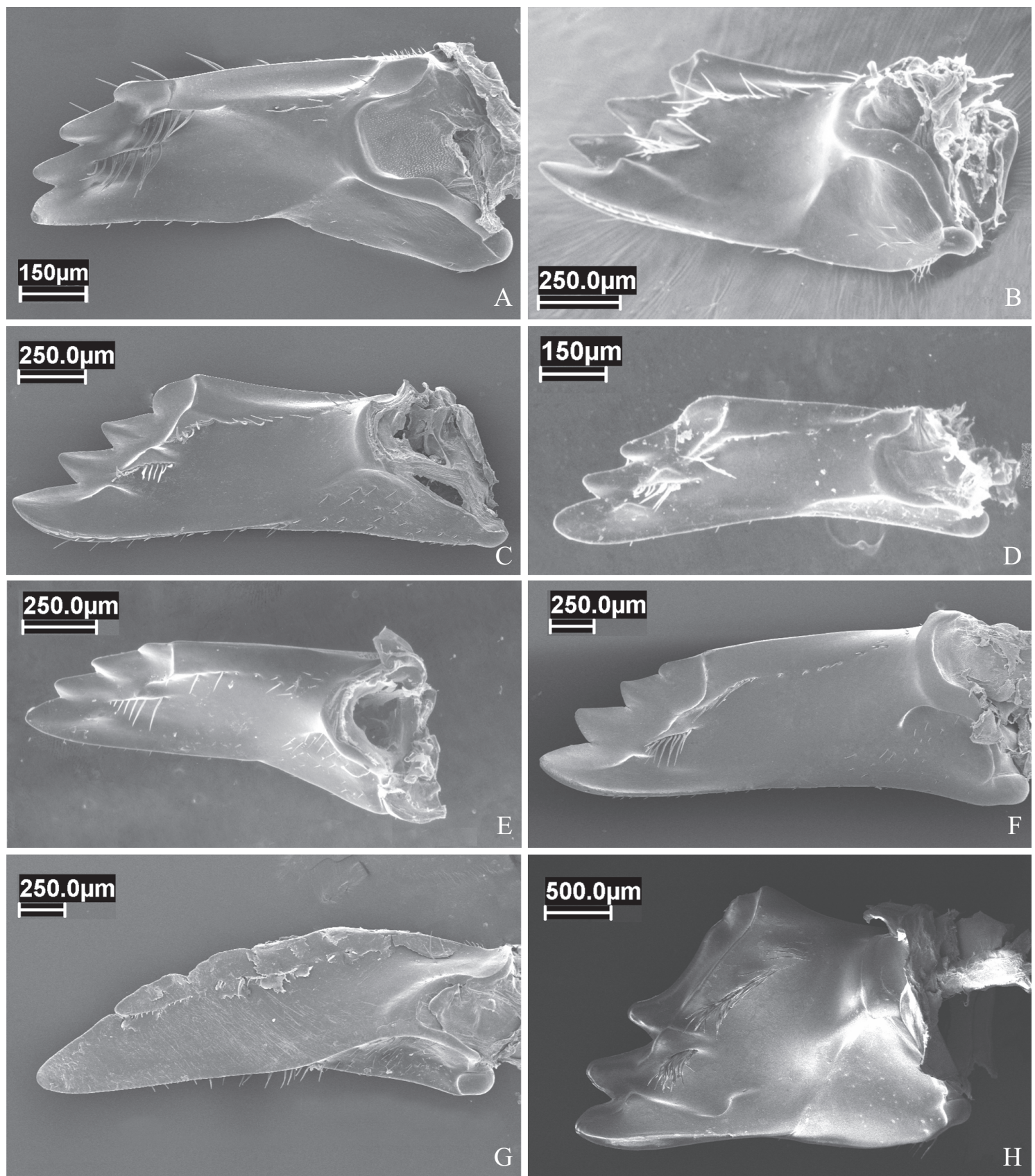

Fig. 7. Mesal view of mandible in: A- M. nigra; B- A. traili; C- C. weyrauchi; D- C. apicepennis; E- E. tatua; F- S. surinama; G- M. dimidiata; H- V. analis

sions relative to body size might be expected on a mechanical basis, and has also been found in euglossine bees (Darveau et al. 2005).

Figure 8 presents scatterplots and the coefficients of ordinary least squares (OLS) regressions of log-transformed length (1Lmd) and width (1Wmd) of mandible on size as represented by the height of mesopleuron (1Mph) for 94 polistine species. Both variables are similarly highly correlated with size $(r=0.92)$, but their interspecific allometric relations differ, with the length variable being nearly isometric $(\mathrm{b}=$ $0.98)$, while the width variable is slightly positively allometric $(b=1.11)$. This means that small size-related differences between species should be expected with respect to mandible's width, more notably between species at the extremes of the size gradient. However, interspecific allometry is an empirical relationship that normally varies according to a particular partitioning of the data, and its causes or significance are still contentious issues (Harvey \& Pagel 1991; Martin et al. 2005; Steudel 1982). In some cases, knowledge about the properties of a system allows one to make predictions about allometric coefficients based on functional properties of the corresponding systems' elements. In polistine wasps, Silveira \& Caetano (1993) found the allometric coefficient for the length of venom gland filaments across a diverse array of 
species to be very close to the value of 1.5 , expected in cases of compensatory increase of secretory surface.

For the present mandible dataset, analyses of the bivariate relationships in subsamples, like genera or larger clades reveal considerable variation, with the slope of regression lines for the length variable being slightly higher in most of the epiponine genera and clades as compared to Polistes, Mischocyttarus and the Ropalidiini. As to the width variable, a similarly clear pattern can not be observed, and variation between taxa is a little larger. Steudel (1982) considers that interspecific allometric curves may be seen eventually as artifactual patterns or as summaries of the consequences of size across all the included groups, which may be heavily influenced by the differing adaptations of those groups.
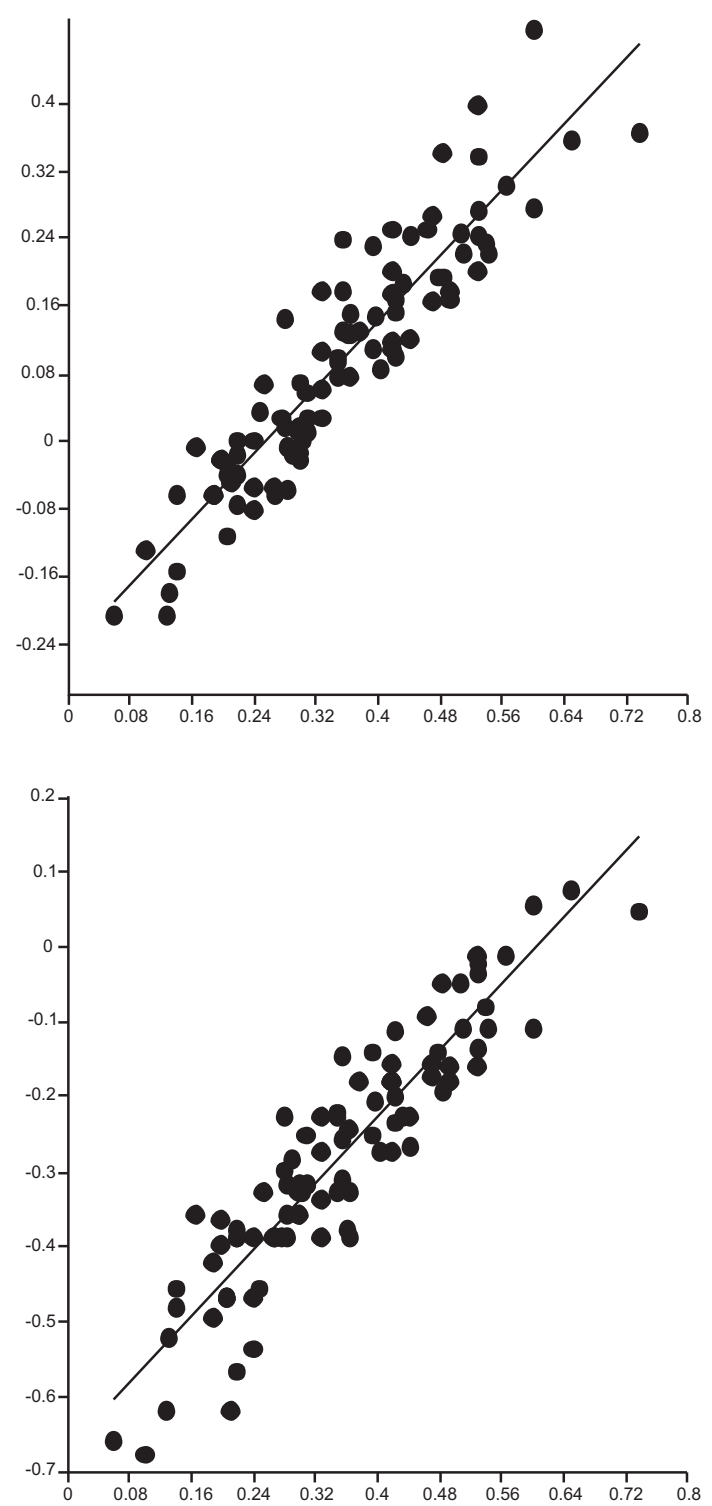

Fig. 8. Ordinary least squares regressions of (A) length (ILmd) and (B) width (lWmd) respectively of mandible on body size as estimated by mesopleuron height (1Mph). All variables log transformed; coefficients as follows 1Lmd: a $=0.98, \mathrm{~b}=-0.25, \mathrm{r}=0.92 ; 1 \mathrm{Wmd}: \mathrm{a}=1.11, \mathrm{~b}=-0.67, \mathrm{r}=0.92$.
When information on phylogenetic relationships between species is introduced into the regressive model using the PGLS method (as described by Revell [2009]), the values of allometric coefficients result nearly the same as in OLS (1.02 and 1.12 respectively for $1 \mathrm{Lmd}$ and $1 \mathrm{Wmd}$ ). Figure 9 shows scatterplots of the residuals of length and width variables simultaneously, obtained with the two kinds of methods. The intersection between the axes marks the value $(=0)$ representing the expected shape of the mandible for Polistinae at any given size. Phylogenetic correction produces very small alteration in the relative positions of species within the cloud of points, with a Mantel correlation test performed between the interspecies distance matrices implied by the two sets of points reaching a very high value of 0.99 . The main differences resulting from application of the PGLS method is the slight horizontal compression of the data and a more accentuated translation of the reference zero to a position further leftwards within the cloud of points. Changes on parameters and position of the regression lines result from different weighting of the observations in the PGLS method, according to shared components of variation reflecting common phylogenetic history (see Pagel 1993; Rohlf 2001). In the present case, however, the arbitrary use of unitary branch lengths gives only a crude estimation of what the relevant variance-covariance structure would look like, since phylogenetic distance is determined solely by the number of intervenient nodes along a given path in the tree. This is directly influenced by the number of sampled species in each genera or clade, and in the opposite direction by the occurrence of polytomies (or unknown phylogenetic relationships). Furthermore, the use of unitary branch lengths implies assuming a kind of punctuated model of evolution, with change occurring mainly during speciation events (Hansen \& Martins 1996).

At this point, a practical matter refers to choosing a slightly different basis for judgments on whether a species has a mandible that is "long and narrow" or "short and wide" (or long and broad, or short and narrow) to its body size. Because the difference is small, not affecting interspecies' relations and the classification of more extreme (and more interesting) shape deviations, we follow here the conservative approach of using the OLS residuals, also keeping in mind the arguments of Rohlf (2006) that the main advantage in using phylogenetic methods is statistical, related to error rates and power, and that from this is not ensured a better estimate in any particular data set.

Species comparisons. Comparison between species is here attained by using as tip data the residuals of the regressions just considered, as well as the ratio variable R. This "slenderness" ratio seems useful as a preliminary measure of quantitative comparison between genera and species. The weak negative correlation between $\mathrm{R}$ and the size-variable Mph $(\mathrm{r}=-0.24)$ indicates that it indeed may be seen as a relatively size-free indicator of mandible shape if scope of the analysis is set to the Polistinae as a whole. This small correlation reflects the interspecific allometric relation between the mandible's width and length variables. Visual inspection of the plot of $\mathrm{R}$ against 

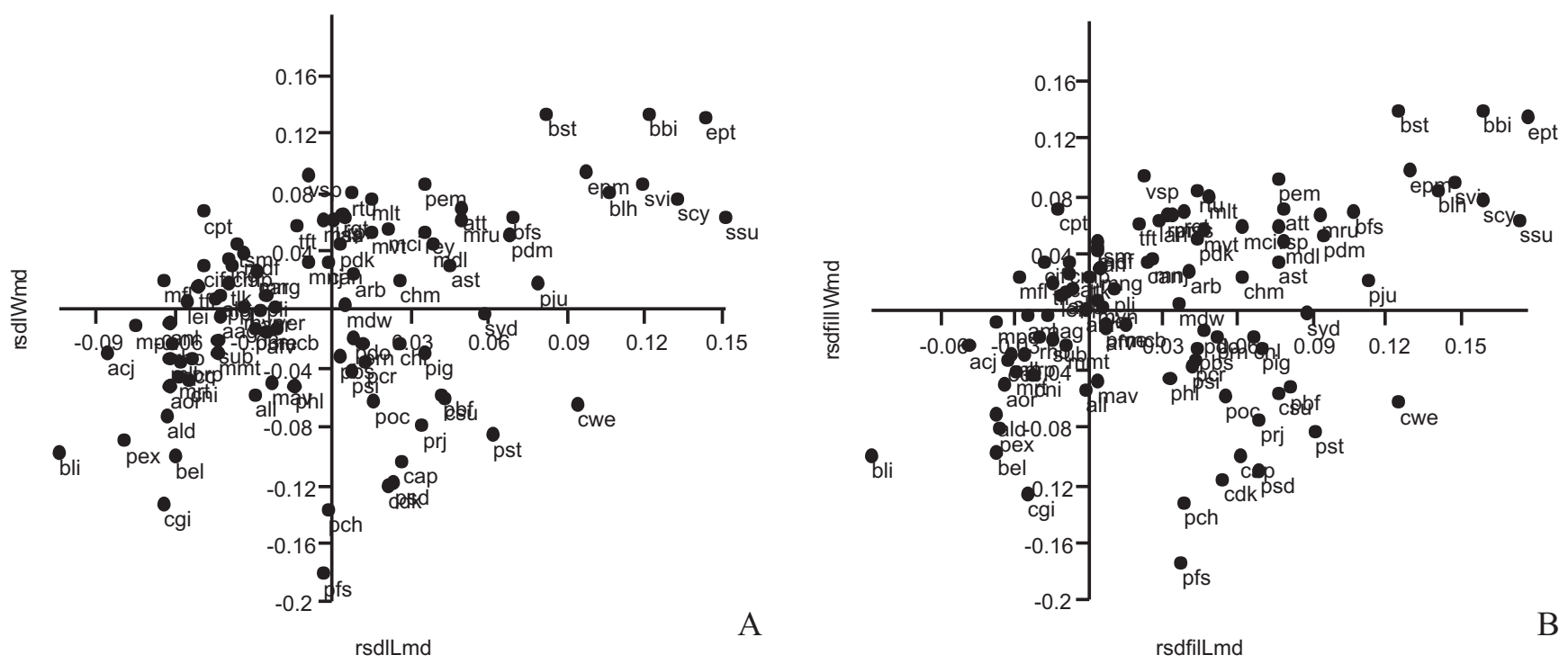

Fig. 9. Ordinary (A) and Phylogenetic (B) residuals of regressions of length (rsdlLmd; rsdfilLmd) and width (rsdlWmd; rsdfilWmd) respectively of mandible on body size as estimated by mesopleuron height. All variables log transformed. Coefficients of phylogenetic regressions as follows $1 \mathrm{Lmd}$ : $\mathrm{a}=$ $1.02, \mathrm{~b}=-0.23 ; \mathrm{Wmd}: \mathrm{a}=1.12, \mathrm{~b}=-0.63$. Species covariance matrix "C" based on species tree of Fig. jjj. Mantel correlation $(\mathrm{R})=0.99$ (between implied interspecies distance matrices).

Mph (Fig. 10) makes apparent the relative size-independence, showing at the same time how large differences can be between species within a given size class.

Figures 12 and 13 show variation of size-corrected variables and the ratio $\mathrm{R}$ for polistine genera and clades, and for a few species of subfamilies Vespinae and Eumeninae. Correlations between variables vary a lot within genera and clades, and are different in general from those observed for the Polistinae as a whole. However, some general trends can be observed in the data: 1) correlations between size-corrected head-width (rsdlHwd) and mandible-length (rsdlLmd) are usually larger than correlations between the head measurement and mandible-width (rsdlWmd). This seems interesting because this latter mandible measure turns to be also an estimate of the head-depth at that point where mandibles articulate to head capsule; 2 ) variation in the ratio $\mathrm{R}$ is largely determined by mandible-width ( $r s d l W m d$ ). This can be easily seen in the mirror-like symmetry presented by graphs corresponding to these two variables; 3 ) the magnitude of variation within clades as estimated by the standard deviation is consistently larger for the mandible-width variable (rsdlWmd), with particularly larger values in the genus Protopolybia and in the Asteloeca-Clypearia clade (Fig. 14).

The polistine basal tribes and basal epiponine genera all show relatively robust mandibles, with the ratio $\mathrm{R}$ never reaching the value of 2.5 (Fig. 12). In Polistes, the mandible is short and broad and the head is relatively narrow in most species (Fig.12A). In Mischocyttarus and in the Ropalidiini there exists more shape variation, but the mandible is nearly always shorter than the expected size-corrected length for the Polistinae (Figs. 12 B, C). In agreement with qualitative characters, information on Apoica species is suggestive of two patterns (Fig.12D), one of them corresponding to A. arborea (which is

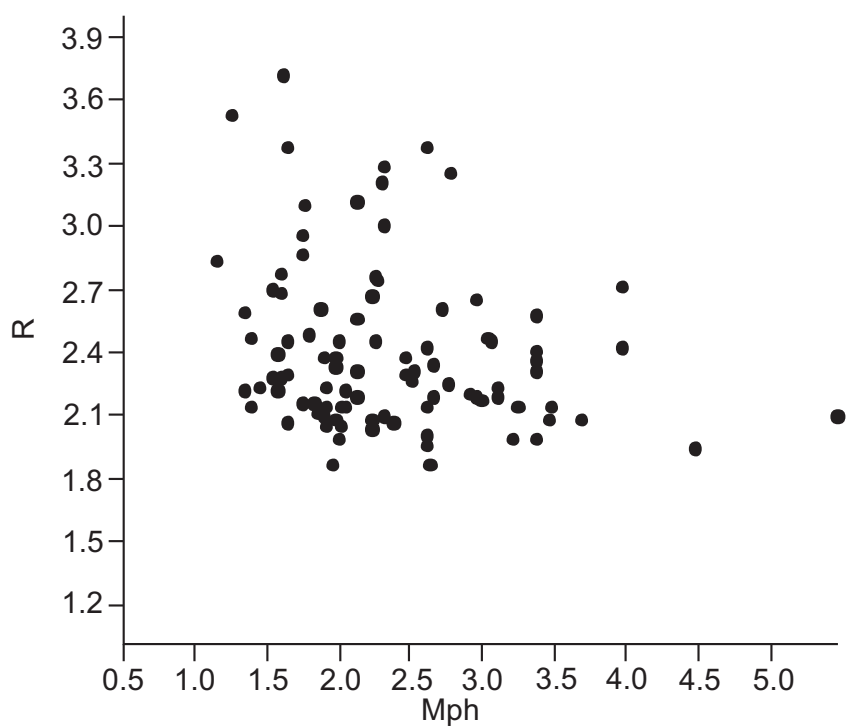

Fig. 10. Scatter plot of values of the ratio (R) between length and width of the mandible against body size as estimated by the height of mesopleuron (Mph). Pearson correlation coefficient $r=-0.24(p=0.021)$.

similar to other basal polistines), and the second one referring to other species in which both mandible measurements are less than the respective expected values,

implying that these species would have "small" mandibles to their body size. The basal epiponine clades AgelaiaAngiopolybia and Pseudopolybia-Leipomeles may be characterized as having relatively narrow heads and short and wide mandibles, with this contrast being more accentuated in the second clade ((Fig.12 E, F). Pseudopolybia langi is very different from congeneric species in respect to headwith, but has a similarly robust mandible. 


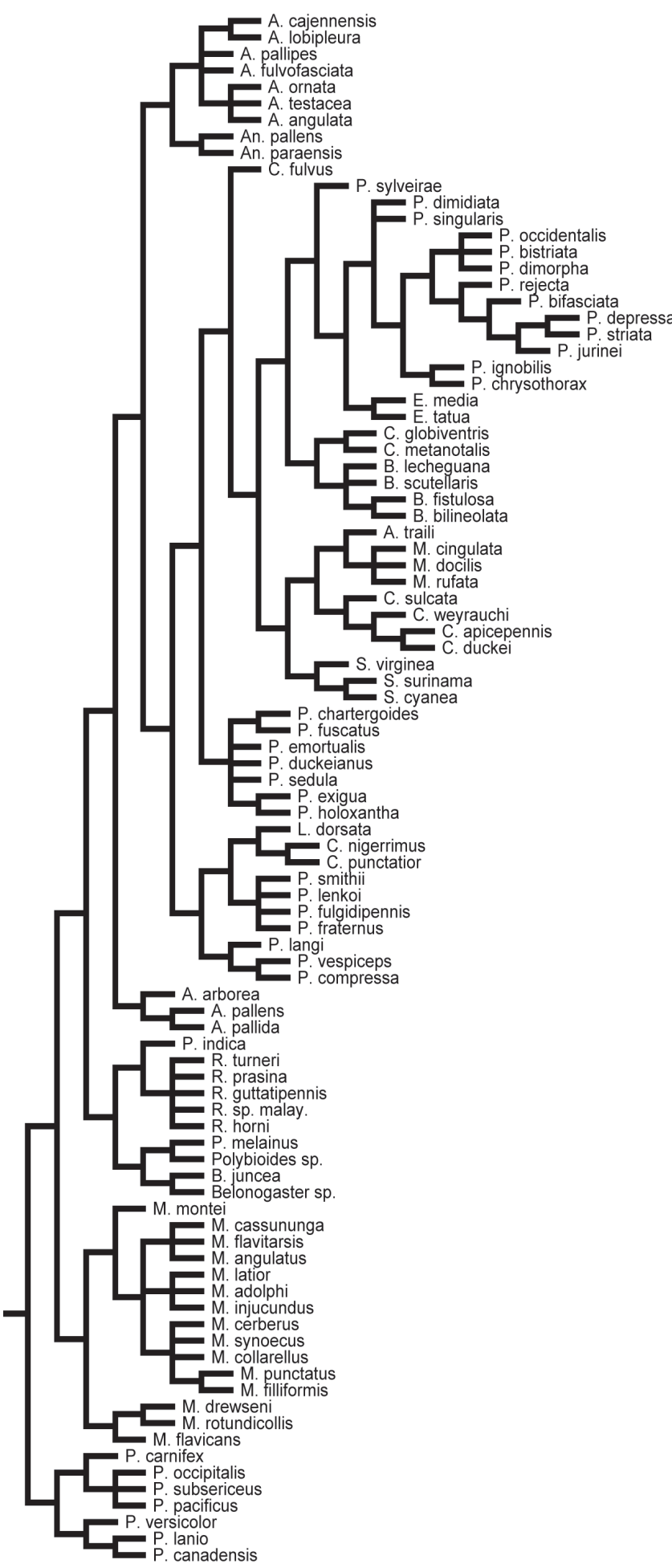

Fig. 11. Phylogeny for the studied wasp species based on the genus level tree published by Wenzel \& Carpenter (1994), corrected for synonymies and extended to species level after Carpenter et al. (1996), Carpenter et al. (2000), Carpenter (2004), Pickett et al. (2006), Pickett \& Wenzel (2007), and Silveira (2008); species "R. sp. malay." is Ropalidia sp. group of malayiana.

In the remaining epiponine species, mandibles tend to be distinctly slender, with the ratio $\mathrm{R}$ equal to or larger than 2.5 in a majority of the cases. However, in some instances, simi- lar values of $\mathrm{R}$ result from different motives. In some genera like Charterginus (Fig.13E) and part of Protopolybia (Fig.13A), high values of $\mathrm{R}$ are caused principally by extreme reduction of the mandible-width (linked to a very shallow head behind composite eyes). In Charterginus fulvus and Protopolybia exigua, as in some Apoica, both length and width of mandible are less than the expected size-corrected values, i.e. the mandible is comparatively small to the wasp's size. On the other hand, in the cases of the genera Polybia (Fig.13C) and (more typically) Clypearia (Fig.13D), whose species also tend to have shallow heads, larger mandible lengths further contribute to enhance the characteristic slender shape of the mandibles.

Other instances of similarity in $\mathrm{R}$ values which seem related to different causes refer to the genera Brachygastra, Synoeca and Epipona. In the first genus (Fig.13B), mandibles in particular are simply very large to body size, while in the other two genera head as a whole (and mandibles) is enlarged relative to general body size (Fig.13 D, E). Interestingly, as described before, several other qualitative morphological features are shared by these genera, which seem to be associated to the strong torsion of the distal part of the mandible (Figs. 1 D, E, F; 2 B, D, F; 3 J, K, L).

The few species sampled of other vespid subfamilies (Fig.13F) suggest that patterns of morphometric variation in the Vespinae may be similar to those observed in Polistinae, being largely determined by the width dimension of the mandible. As to the Eumeninae, however, the length dimension is predicted to assume a leading role in determining mandible shape variation among major clades.

Mechanical interactions among mandible structural elements. Vespid mandibles are closed by the action of powerful adductor muscles, and move below the head capsule along a transversal direction in such a way that the apex of one mandible may pass just beneath the apex of its opposite counterpart. Further inward movement leads one mandible to rest upon the other, in an overlapping manner (Fig. 1 C, D, E, F; see also Duncan 1939). In addition to direct scrapping and crushing actions of apical teeth and mesial elements (denticles, anterior carina) upon materials, mechanical interactions may take place among main structural elements along the mandible closing trajectory (see Fig. 1 C-F): a) opposition and crossing of mandibles' apical teeth at the middle of the closing trajectory; b) shearing action of the apical teeth against mesial denticles of the opposite mandible (occurring just after the mandibles cross each other); c) shearing action of the mandible anterior margin against the ventral margin of the clypeus (strictly not a mouthpart).

These mechanisms probably do not have the same importance in every context of use, or even the same efficiency between different mandible morphological types. Observation of lab reared female individuals of $M$. cerberus, during catching and malaxation of dead drosophilid flies or pieces of caterpillars showed that the amplitude of mandible movement is large enough to allow the combined actions of all those structural elements in promoting cutting, shearing or 

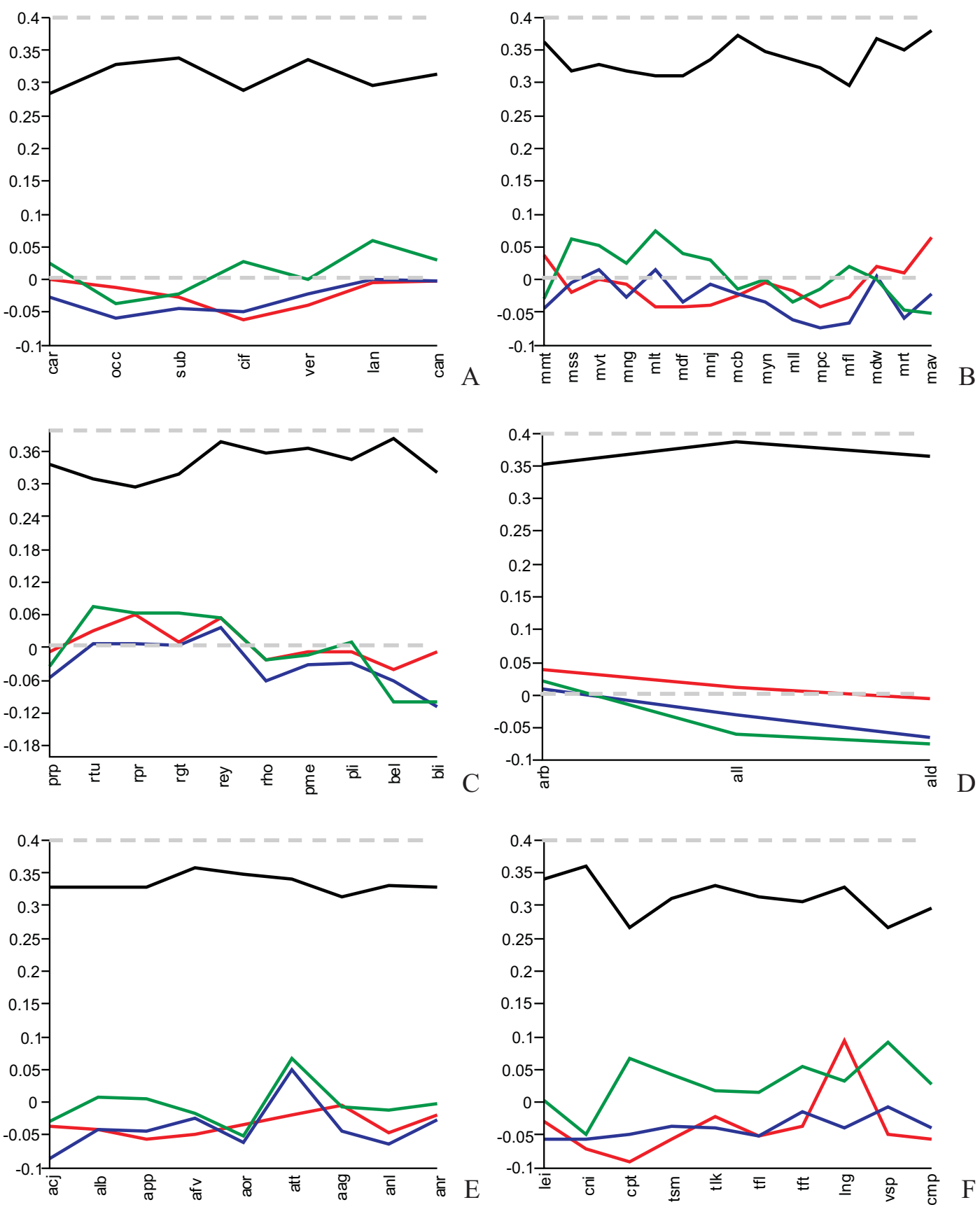

Fig. 12. Graphs showing variation and interrelationships of four studied variables within major polistine taxa; black line: ratio (R) between length and width of mandible; red line: size-corrected head width (rsdlHwd); blue and green lines: size-corrected length (rsdlLmd) and width (rsdlWmd) respectively of mandible; $\mathrm{R}$ is in logarithmic scale for easy of comparison; dashed grey lines mark $y$ values $(0.4)$ where $\mathrm{R} \sim 2.5$, and $(0)$ where regressed variables present the expected value for a given size; order of species in the $x$ axis is arbitrary; names under acronyms as in appendix 1. A- Polistes, B-Mischocyttarus, C- Ropalidiini, D- Apoica, E- Agelaia-Angiopolybia, F- Pseudopolybia-Leipomeles.

crushing effects. Duncan (1939) had previously commented on the alternating positions of apical teeth and mesial denticles in Vespinae, the anteriormost of which he called "molar shelf".

In $M$. cerberus, the acute blade-like form of the anterior margin of the mandible at one side, and the sharp ventral margin of the clypeus at the other allow to anticipate a kind of scissors-like function of these structural parts that may be quite effective in some contexts. The perfect shape correlation between mandible and clypeus profiles, as well as the close juxtaposition of parts in their relative movement may be observed in virtually every polistine possessing the short robust kind of mandible (Fig. 1C). On the other hand, the strong distal torsion of the mandible observed in some genera seems to disrupt this pattern. In genera like Synoeca, Epipona, Brachygastra and some Protopolybia (and 

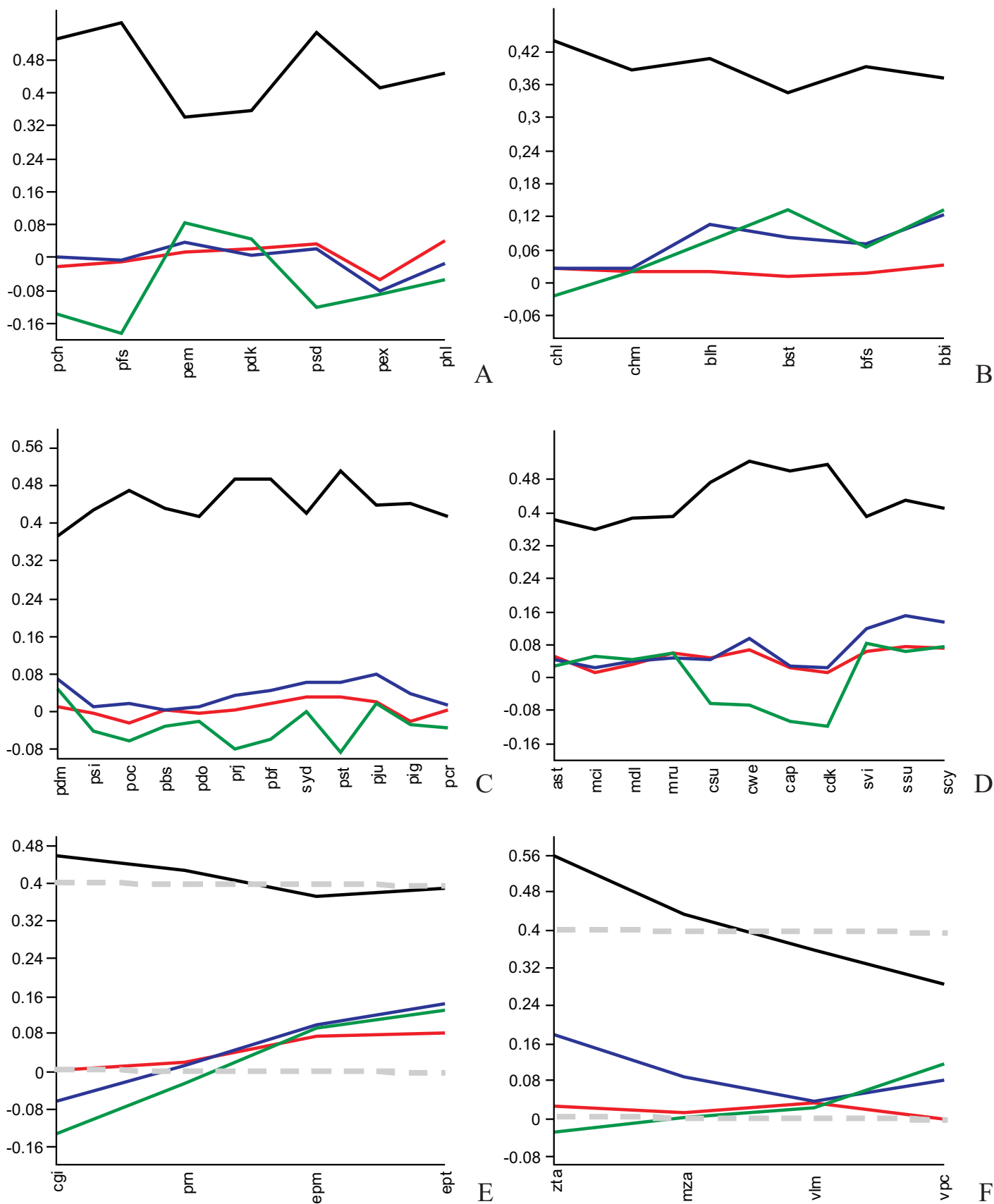

Fig. 13. Graphs showing variation and interrelationships of four studied variables in polistine taxa and some vespine and eumenine species; black line: ratio $(\mathrm{R})$ between length and width of mandible; red line: size-corrected head width (rsdlHwd); blue and green lines: size-corrected length (rsdlLmd) and width (rsdlWmd) respectively of mandible; $\mathrm{R}$ is in logarithmic scale for easy of comparison; dashed grey lines mark $y$ values where $\mathrm{R} \sim 2.5$ (0.4), and where regressed variables present the expected value for a given size (0); order of species in the $x$ axis is arbitrary; names under acronyms as in appendix 1. A-Protopolybia, B-Chartergus-Brachygastra, C-Polybia, D-Asteloeca-Clypearia, E- Charterginus, Protonectarina, Epipona, F- Eumeninae, Vespinae.

Ropalidia), the form of the mandible anterior margin is modified in such a way that it loses the typical "scimitar" profile, being instead as a straight and blunt border. Correspondingly, in these taxa the mandibles do not perfectly oppose to the clypeus margin when in a resting position (Figs. $1 \mathrm{D}, \mathrm{E}$ ). It is possible that in these taxa, a similar scissors-like action has been transferred to the region of the apical teeth, whose anterior edges align in a coplanar fashion, being able to pro- duce shearing interactions against their opposite counterparts when the two mandibles cross at the middle of the closing trajectory (Figs. 1 D-F). It also should be noted that mesial denticles are greatly reduced in these taxa. A similar functioning of the mandibles is apparent in vespines, possibly accomplished solely by the exceptionally wide tooth 3 , which has a sinuous very long and sharp anterior border, positioned in a nearly vertical orientation (Fig. $7 \mathrm{H}$ ). 


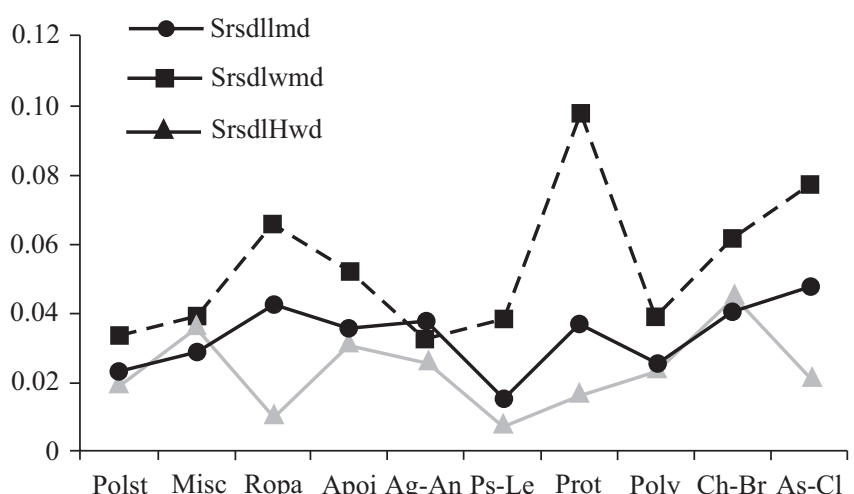

Fig. 14. Line graphs showing differences in magnitude of standard deviation of size-corrected variables: length (Srsdllmd) and width (Srsdlwmd) of mandible, and head width (SrsdlHwd), for Polistes (Polst), Mischocyttarus (Misc), Ropalidiini (Ropa), Apoica (Apoi), Agelaia-Angiopolybia (Ag-An), Pseudopolybia-Leipomeles (Ps-Le), Protopolybia (Proto), ChartergusBrachygastra (Ch-Br), and Asteloeca-Clypearia clades (As-Cl).

While considering the aspect of mechanical advantage of vespid mandibles as lever systems, Hansell (1987) remarked on the relevance of a ratio between the mandible length and the distance from the basal articulation to the insertion of the "closer muscle tendon" (i.e. the ratio between the resistance and force arms respectively acting around a fulcrum). In order to estimate the second distance, the author considered the lesser diameter of the basal transversal section of the mandible. However, in comparisons across different subfamilies, involving extremely elongated versus very short mandibles, e.g. between Eustenogaster calyptodoma and Polistes meadeanus as in Hansell's Fig.11, differences in that ratio are mainly determined by differences in the length of the mandible (the resistance arm). Furthermore, because the mandible rotates around its articulation axis, while muscular force is applied along an invariant oblique direction, length of the force arm can be augmented by moving the point of attachment of the muscle apodeme inwards, further away from the basal margin, i.e. by means of a deeper mesial emargination. A deep emargination seems to be the prevailing condition in Polistinae, but a relatively shallow emargination can be noted in various species, like Apoica arborea (Fig. 4D), Mischocyttarus drewseni (Fig. 4F), Chartergus globiventris (Fig. 6C), Brachygastra bilineolata (Fig. 6D), Protonectarina sylveirae (Fig. 6G), Synoeca surinama (Fig. 7F), and Vespa analis (Fig. 7H).

Mandibular morphological features as adaptations. The papers by O'Donnell (1995) and Sarmiento (2004) have been major advances in the knowledge of factors capable of driving evolutionary changes in the morphology of the vespid mandible. However, both works encountered problems partly related to the incompleteness of their databases, as well as from the lack of previous basic morphological studies with standard descriptions and nomenclature. O'Donnell (1995) commented on the adaptive nature of the shape of the "dorsal mesal tooth" in species of Agelaia, Angiopolybia and Apoica, as being "elongated into an acute, blade-like ridge that spans the length of the mandible". O'Donnell's presented a fairly precise description of this structure (named here as the posterior mesial denticle), presenting it as a structural modification in these genera for collecting of flesh from carcasses. Necrophagy in Apoica was predicted by the author from morphology alone.

However, the condition described by O'Donnell (1995), in which the posterior denticle has a prominent (abrupt and distally projecting) extremity is primitive in Polistinae, and considerable variation in height and extension of the denticle exists in Agelaia and Angiopolybia (4 G, H; 5 A, B), as well as in other polistine basal genera (Fig. 4 and 5). Furthermore, similarly well-raised denticles may occur even in epiponine genera like Chartergus (Fig. 6C) and in species of Polybia, such as $P$. dimidiata (Fig. 5E) or P. singularis. Incidentally, another structure on the mesial side of the mandible which is synapomorphic in Agelaia and Angiopolybia may give support to the association between necrophagy and mandible morphology. In these two genera, the outer element of the anterior denticle and the mesial anterior carina are exceptionally prominent (Figs. $4 \mathrm{G}, \mathrm{H} ; 5 \mathrm{~A}, \mathrm{~B}$ ), forming a distinctly well-developed "molar shelf" (in the terminology of Duncan 1939). Similar shapes may eventually be found in a few other cases like Apoica (but not in A. arborea), Parapolybia, and Polybioides, but never in so exaggerated a manner (compare Figs. 4 B, C). Silveira et al. (2005) presented results of intensive experiments with carrion traps in a rainforest in Brazilian Amazonia (Caxiuanã, PA), and reported that only Agelaia and Angiopolybia (six species in total) were captured in these traps, with high frequency and abundance. Previous literature records on necrophagy by other genera (Brachygastra, Parachartergus, Polybia, and Synoeca; see O'Donnell 1995) were not confirmed.

Sarmiento (2004) also reported significant correlation between height and length (i.e. prominence) of mandible mesial denticles (his ventral and dorsal teeth) and some categories of nest construction materials used by polistines: long wood fibers, short wood fibers, and plant hairs. The author found that species that use long fibers tend to have more prominent mesial denticles, while those that use short fibers have less developed denticles. Findings of the present work are in general agreement with those results, but make new additions in some important respects. The distribution of the qualitative categorical states used here to describe shape variation of the mesial denticles shows that more extremely reduced forms of these structures (including the anterior denticle and carina) indeed are presented mostly by species that use short fibers in the genera Synoeca, Clypearia, Brachygastra, Epipona, and some Polybia (Figs. 5 F, H; 6 B, D; 7 C-F). However, several species of the latter genus have quite well-developed mesial structures, like $P$. serice and $P$. jurinei (Figs. $5 \mathrm{G} ; 6 \mathrm{~A}$ ) and $P$. dimidiata (Fig. 5E), the same applying to species of Metapolybia and Asteloeca (Figs. 7 A, B) in the astelocyttarous-nest clade. On the other hand, species of the genera Protopolybia, Charterginus and Protonectarina, which use long fibers, have poorly developed mesial structural elements (Figs. 6 E-H). 
Extreme reduction of mesial denticles is associated to torsion of the distal part of the mandible, as well as other morphological features, like the shape of the anterior margin. Visual comparison on a phylogeny of the distribution of inferred ancestral states of morphological characters versus categories of nest material (Fig. 15; using parsimony reconstruction in Mesquite) shows that modifications of the primitive Polistes or Agelaia types of mandible begin to appear just outside of epiponine clades in which short fiber is the prevailing nest construction material. Character transformations referring to significant alteration in the shape of mandible anterior margin (character 4: $0>1$; see matrix and Fig. 15), shape of teeth 1 and 2 (character 5: $0>1$ ), shape of tooth 4 (character 7: $0>1$, in two of three maximum parsimony resolutions, or MPRs), shape of anterior mesial denticle and carina (character 8: $0>4$ ), shape of the posterior denticle (character 10: $0>2$ ), degree of mandible torsion (character 12: $0>2$ ), are inferred to have occurred in the ancestor of the component Protopolybia-Clypearia. In most cases, inferred changes at this level of the phylogeny imply in subsequent reversals independently within Polybia and in the Asteloeca-Synoeca component, as to account for plesiomorphic conditions in these clades. However, as mainly indicated in Sarmiento's results, those most extremely transformed mandibles seem to occur precisely in genera that use short fibers, which might be also the case of Ropalidia sp. gr. Malayana. Fiber type used by Protopolybia emortualis is scored as unknown, and this behavioral trait is considered to vary in Brachygastra by Sarmiento (2004). It seems possible that rather than being the factor that actually promoted selection of these more deviant shapes, evolutionary change related to the use of short fibers has instead been a factor that liberated mandible morphology to evolve in response to other yet unknown functional requirements. More information is needed on aspects like kind of food items, their size and hardness, as well as direct observation of mandible functioning in the various contexts in which it is used by polistine wasps.

Basic data for phylogenetic studies. Information on mandible characters and states are summarized in the matrix of Tables I, II, with the morphometric ratio (R) coded arbitrarily for some species as a categorical variable with four states. Inferred ancestral character state transformations are also mapped on phylogenetic trees (Figs. 15, 16), using parsimony-based optimization. These characters are expected to be useful at various taxonomic levels, and further more detailed observations may reveal additional morphological diversity inside genera or species groups. At the subfamily level, it would be useful to test the cladistic potential of two sets of similarities regarding derived features, one involving the genera Synoeca, Epipona and Brachygastra (and also part of Protopolybia and one species in Ropalidia), and the other encompassing principally the genera Protopolybia and Charterginus (but marginally involving also Protonectarina). Similarity is remarkable in both cases (see descriptions, Tables I, II and Figs. 6 E-H, 6
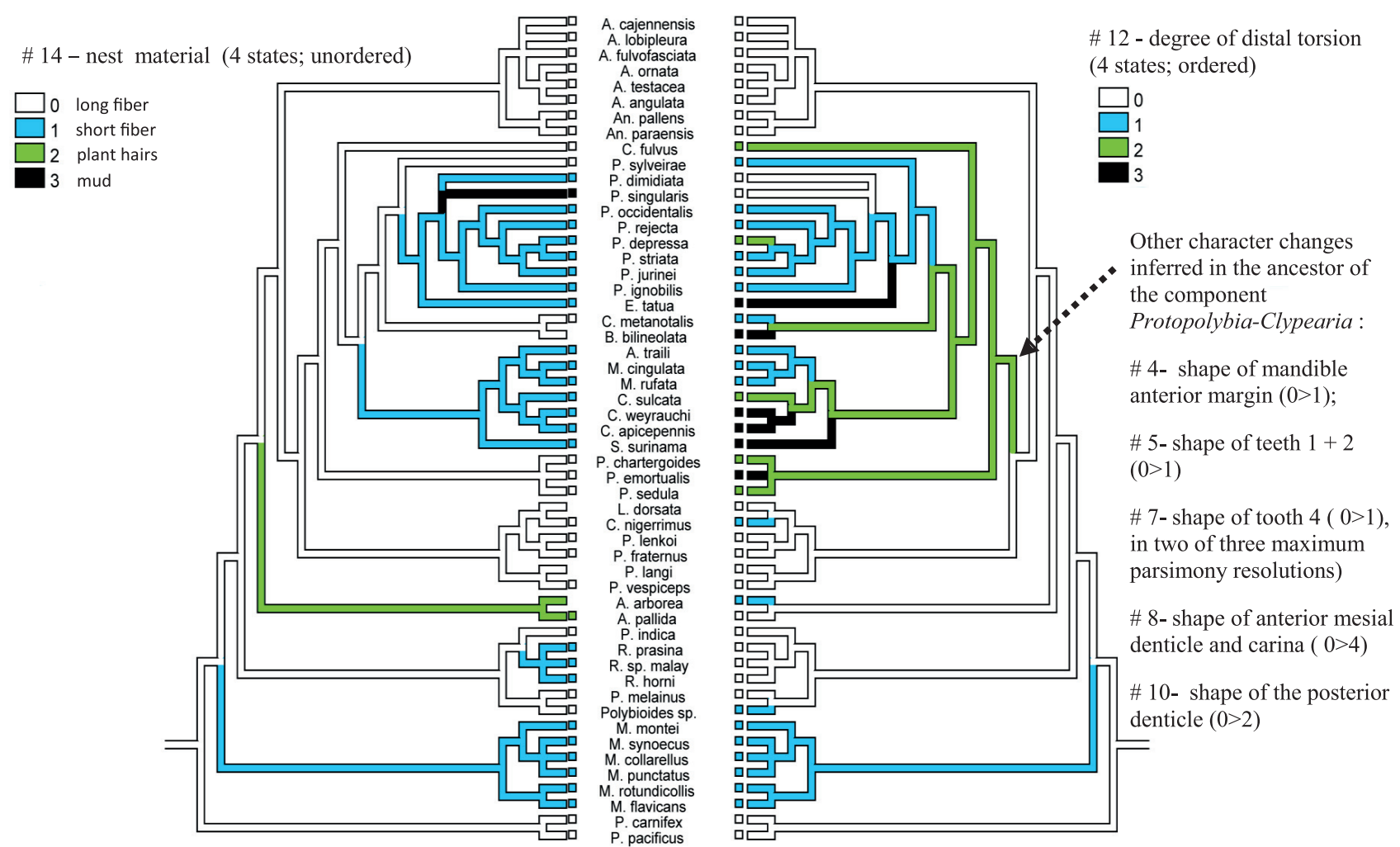

Fig. 15. Mirrored phylogenetic trees (for a subset of 53 wasp species), showing parsimony reconstruction of ancestral states for six mandible characters (\#) (right-side tree) compared to categorical states referring to type of nest construction material (left-side tree). 


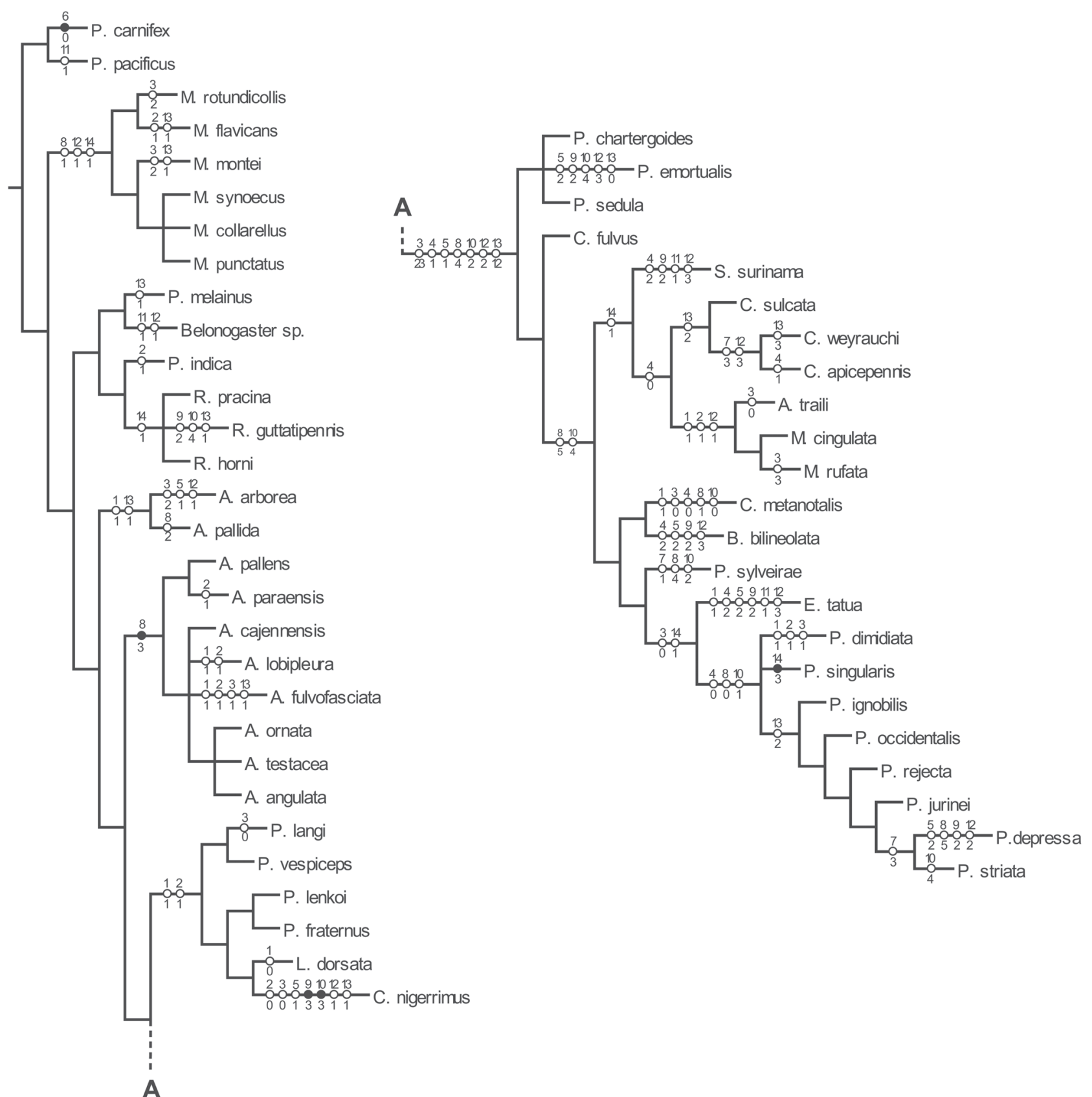

Fig. 16. Parsimony optimization of 14 mandibular and nesting characters along a tree representing the phylogenetic hypothesis adopted in this work assuming accelerated transformations. Character numbers and states as in Tables I, II.

$\mathrm{D}$ and $7 \mathrm{E}-\mathrm{F}$ ), and is in partial agreement with alternative evidence presented by Silveira \& Silveira (1994) regarding characters of the sting apparatus. In Synoeca and Epipona, the spiracular plates of the sting apparatus have much the same form, with variable degree of reduction of the dorsal medially connecting bar. Regarding the other pair of genera, shape of the sting's second rami in Charterginus fulvus was observed to be very similar to Protopolybia species, while being more like the primitive state in $C$. weyrauchi, and with $C$. xanthura showing an intermediate form. Interestingly, with respect to mandible shape, $C$. weyrauchi presents a more planar man- dible, with the posterior margin less sinuous, more like the condition observed in basal polistine taxa.

\section{ACKNOWLEDGMENTS}

We thank the Brazilian Council for Science and Technology $(\mathrm{CNPq})$ for financial support. MSc. Antonio da Silva Silveira helped with the program Matlab. We are also grateful to Dr. José Alexandre Diniz-Filho and Dr. James Carpenter for reading a first version of the manuscript, and to Dr. Junichi Kojima for donation and identification of ropalidiine 
species. Two anonymous referees also contributed with their critics and suggestions.

\section{REFERENCES}

Carpenter, J. M. 1982. The phylogenetic relationships and natural classification of the Vespoidea (Hymenoptera). Systematic Entomology 7: 11-38.

Carpenter, J. M. 1991. Phylogenetic relationships and the origin of social behavior in the Vespidae, p. 7-32. In: K. G. Ross \& R. W. Matthews (eds.). The Social Biology of Wasps. Ithaca, Cornell University Press, $678 \mathrm{p}$.

Carpenter, J. M. 1996. Phylogeny and biogeography of Polistes, p. 18-57. In: Turillazzi, S. \& West-Eberhard, M. J. (eds.). Natural History and Evolution of Paper-Wasps. Oxford, Oxford University Press, $400 \mathrm{p}$.

Carpenter, J. M. 2004. Synonymy of the genus Marimbonda Richards 1978, with Leipomeles Möbius 1856 (Hymenoptera: Vespidae; Polistinae), and a new key to the genera of paper wasps of the New World. American Museum Novitates 3465: 1-16.

Carpenter, J. M. \& J. Kojima. 1997. Checklist of the species in the subfamily Vespinae (Insecta: Hymenoptera: Vespinae). Natural History Bulletin of the Ibaraki University 1: 51-92.

Carpenter, J. M.; J. W. Wenzel \& J. Kojima. 1996. Synonymy of the Genus Occipitalia Richards 1978, with Clypearia de Saussure 1954(Hymenoptera: Vespidae; Polistinae, Epiponini). Journal of Hymenoptera Research 5: $157-165$

Carpenter, J. M.; J. Kojima \& J. W. Wenzel. 2000. Polybia, Paraphyly, and Polistine Phylogeny. American Museum Novitates 3298: 1-24.

Chapman, R. F. 1964. The structure and wear of mandibles in some African grasshoppers. Proceedings of the Zoological Society of London 142: 107-121.

Chapman, R. F. 1995. Mechanics of food handling by chewing insects, p. 3-27. In: Chapman R. F. \& G. de Boer. (eds). Regulatory Mechanisms in Insect Feeding. New York, Chapman \& Hall, 398 p.

Darveau, C.-A.; P. W. Hochachka; K. C. Welch Jr.; D. W. Roubik \& R. K. Suarez. 2005. Allometric scaling of flight energetics in Panamanian orchid bees: a comparative phylogenetic approach. Journal of Experimental Biology 208: 3581-3591.

Downing, H. A. \& R. L. Jeanne. 1982. A description of the ectal mandibular gland in the paper wasp Polistes fuscatus (Hymenoptera: Vespidae). Psyche 89: 317-320.

Duncan, C. D. 1939. A contribution to the biology of North American vespine wasps. Stanford University Publications in Biology 8: 1-272.

Hammer, Ø.; D. A. Harper \& P. D. Ryan. 2001. PAS: Palaeontological Statistical package for education and data analysis. Palaeontologia Electronica 4: 9 p.

Hansell, M. 1987. Nest building as a facilitating and limiting factor in the evolution of eusociality in the Hymenoptera, p. 155-181. In: P. Harvey \& L. Partridge. (eds). Oxford Surveys in Evolutionary Biology. New York, Oxford University Press, 284 p.

Hansen, T. F. \& E. P. Martins. 1996. Translating between microevolutionary process and macroevolutionary patterns: the correlation structure of interspecific data. Evolution 50: 1404-1417.

Harvey, P. H. \& M. D. Pagel. 1991. The comparative method in evolutionary biology. Oxford, Oxford University Press, 239 p.

Hermann, H. R.; A. N. Hunt \& W. F. Buren. 1971. Mandibular gland and mandibular groove in Polistes annularis (L.) (Hymenoptera: Vespidae). International Journal of Insect Morphology and Embryology 1: 43-49.

Hunt, J. H. 1999. Trait mapping and salience in the evolution of eusocial vespid wasps. Evolution 53:225-237

Kojima, J. \& J. M. Carpenter. 1997. Catalogue of species in the Polistine tribe Ropalidiini (Hymenoptera: Vespidae). American Museum Novitates 3199: 1-96.

Maddison, W. P. \& D. R. Maddison. 2009. Mesquite: a modular system for evolutionary analysis. Version 2.72 Available from http://mesquite project.org (accessed 23 April 2010).

Martin, R. D.; M. Genoud \& C. K. Hemelrijk. 2005. Problems of allometric scaling analysis: examples from mammalian reproductive biology. Journal of Experimental Biology 108: 1731-1740

O'Donnell, S. 1995. Necrophagy by neotropical swarm-founding wasps (Hymenoptera: Vespidae, Epiponini). Biotropica 27: 133-136.

O'Donnell, S. 2003. The development of biting interactions and task performance in a tropical eusocial wasp. Behaviour 140: 255-267.

Pagel, M. 1993. Seeking the evolutionary regression coefficient: An analysis of what comparative methods measure. Journal of Theoretical Biology 164: 191-205.

Pickett, K. M. \& J. W. Wenzel. 2007. Revision and cladistic analysis of the nocturnal wasp genus Apoica Lepeletier (Hymenoptera: Vespidae; Polistinae, Epiponini). American Museum Novitates 3562: 1-30.

Pickett, K. M.; J. M. Carpenter \& W. C. Wheeler. 2006. Systematics of Polistes (Hymenoptera: Vespidae), with a phylogenetic consideration of Hamilton's haplodiploidy hypothesis. Annales Zoologici Fennici 43: $390-406$

Pickett, K. M. \& J. M. Carpenter. 2010. Simultaneous analysis and the origins of sociality in the Vespidae (Insecta: Hymenoptera). Arthropod Systematics and Phylogeny 68: $3-33$

Revell, L. J. 2009. Size-correction and principal components for interspecific comparative studies. Evolution 63: 3258-3268.

Richards, O. W. 1962. A revisional study of the masarid wasps (Hymenoptera, Vespoidea). London, British Museum (Natural History), 294 p.

Rohlf, F. J. 2001. Comparative methods for the analysis of continuous variables: geometric interpretations. Evolution 55: 2143-2160.

Rohlf, F. J. 2006. A comment on "Phylogenetic correction". Evolution 60 1509-1515.

Sarmiento, C. E. 2004. A test of adaptive hypotheses: Mandibular traits, nest construction materials, and feeding habits in neotropical social wasps (Vespidae, Polistinae). Insectes Sociaux 51: 387-391.

Silveira, O. T. \& F. H. Caetano. 1993. A morphometric study of sting glands in vespid wasps (Hymenoptera, Vespidae). Sociobiology 23: 45-62.

Silveira, O. T. \& A. T. Silveira. 1994. Comparative morphology of skeletal parts of the sting apparatus in neotropical polistine social wasps. Sociobiology 25: $295-327$

Silveira, O. T.; M. C. Espósito; J. N. Santos Júnior \& F. F. Gemaque Júnior. 2005. Social wasps and bees captured in carrion traps in a rain forest in Brazil (Hymenoptera: Vespidae; Apidae). Entomological Science 8: $33-39$

Silveira, O. T. 2008. Phylogeny of wasps of the genus Mischocyttarus de Saussure (Hymenoptera, Vespidae, Polistinae). Revista Brasileira de Entomologia 52: 510-549.

Singh, T. \& B. Singh. 1982. Comparative morphological studies on the mandibular gland and mandibular groove in Hymenoptera Apocrita. Journal of Animal Morphology and Physiology 29: 78-84.

Snodgrass, R. E. 1935. Principles of insect morphology. New York \& London, McGraw-Hill Book Co., Inc., 667 p.

Steudel, K. 1982. Patterns of intraspecific and interspecific allometry in Old World primates. American Journal of Physical Anthropology 59: 419-30.

The Mathworks. 2006. Matlab: the language of technical computing (R2006a). The MathWorks Inc., Natick, MA.

Wenzel, J. W. \& J. M. Carpenter. 1994. Comparing methods: Adaptive traits and tests of adaptation, p. 79-101. In: Eggleton, P. \& R. I. Vane-Wright (eds.). Phylogenetics and Ecology. London, Academic Press, 376 p.

Received 18/1/2011; accepted 3/8/2011

Editor: Eduardo A. B. Almeida 
Silveira \& Santos Jr.

Appendix 1. List of the names of the 116 species included in this study and their respective authors, presenting also the name acronyms used in the graphs of Figs. 9, 12 and 13, and the ratio between length and width of mandible for a majority of the species.

\begin{tabular}{|c|c|c|c|c|c|c|c|}
\hline Species name & Author & Acronym & Ratio (R) & Species name & Author & Acronym & Ratio (R) \\
\hline Agelaia angulata & (Fabricius, 1804) & aag & 2.1 & Parachartergus lenkoi & Richards, 1978 & tlk & 2.2 \\
\hline Agelaia cajennensis & (Fabricius, 1798) & acj & 2.1 & Parachartergus richardsi & Willink, 1959 & & \\
\hline Agelaia constructor & (Saussure, 1854) & & & Parachartergus smithii & (Saussure, 1854) & tsm & 2.1 \\
\hline Agelaia fulvofasciata & (Degeer, 1773) & afv & 2.3 & Parachatergus fulgidipennis & (Saussure, 1854) & $\mathrm{tfl}$ & 2.1 \\
\hline Agelaia lobipleura & (Richards, 1978) & alb & 2.1 & Parapolybia indica & (Saussure, 1854) & prp & 2.2 \\
\hline Agelaia ornata & (Ducke, 1905) & aor & 2.2 & Polistes canadensis & (Linnaeus, 1758) & can & 2.1 \\
\hline Agelaia pallipes & (Olivier, 1791) & app & 2.1 & Polistes carnifex & Fabricius, 1775 & car & 1.9 \\
\hline Agelaia testacea & (Fabricius, 1804) & att & 2.2 & Polistes lanio & (Fabricius, 1775) & lan & 2.0 \\
\hline Agelaya myrmecophila & (Ducke, 1905) & & & Polistes occipitalis & Ducke, 1904 & occ & 2.1 \\
\hline Angiopolybia pallens & (Lepeletier, 1836) & anl & 2.2 & Polistes pacificus & Fabricius, 1804 & cif & 2.0 \\
\hline Angiopolybia paraensis & (Spinola, 1851) & anr & 2.1 & Polistes subsericeus & Saussure, 1854 & sub & 2.2 \\
\hline Apoica arborea & Saussure, 1854 & arb & 2.3 & Polistes versicolor & Olivier, 1791 & ver & 2.2 \\
\hline Apoica pallens & (Fabricius, 1804) & all & 2.4 & Polybia bifasciata & Saussure, 1854 & $\mathrm{pbf}$ & 3.1 \\
\hline Apoica pallida & (Olivier, 1791) & ald & 2.3 & Polybia bistriata & (Fabricius, 1804) & pbs & 2.7 \\
\hline Asteloeca traili & (Cameron, 1906) & ast & 2.4 & Polybia chrysothorax & (Lichtenstein, 1796) & pcr & 2.6 \\
\hline Belonogaster juncea & (Fabricius, 1781) & bel & 2.4 & Polybia depressa & (Ducke, 1905) & syd & 2.6 \\
\hline Belonogaster sp. & & bli & 2.1 & Polybia dimidiata & (Olivier, 1791) & pdm & 2.3 \\
\hline Brachygastra bilineolata & Spinola, 1841 & bbi & 2.4 & Polybia dimorpha & Richards, 1978 & pdo & 2.6 \\
\hline Brachygastra fistulosa & Naumann, 1968 & bfs & 2.5 & Polybia ignobilis & (Halliday, 1836) & pig & 2.8 \\
\hline Brachygastra lecheguana & (Latreille, 1824) & blh & 2.5 & Polybia jurinei & Saussure, 1854 & pju & 2.7 \\
\hline Brachygastra scutellaris & (Fabricius, 1804) & bst & 2.2 & Polybia liliacea & (Fabricius, 1804) & & \\
\hline Chartergellus nigerrimus & Richards, 1978 & cni & 2.3 & Polybia occidentalis & (Olivier, 1791) & poc & 2.9 \\
\hline Chartergellus punctatior & Richards, 1978 & $\mathrm{cpt}$ & 1.8 & Polybia rejecta & (Fabricius, 1798) & prj & 3.1 \\
\hline Charterginus fulvus & Fox, 1898 & cgi & 2.9 & Polybia sericea & (Olivier, 1791) & & \\
\hline Charterginus xanthura & (Saussure, 1854) & & & Polybia singularis & Ducke, 1905 & psi & 2.7 \\
\hline Chartergus globiventris & Saussure, 1854 & chl & 2.7 & Polybia striata & (Fabricius, 1787) & pst & 3.2 \\
\hline Chartergus metanotalis & Richards, 1978 & $\mathrm{chm}$ & 2.5 & Polybioides melainus & (Meade-Waldo, 1911) & pme & 2.3 \\
\hline Chaterginus weyrauchi & Richards, 1978 & & & Polybioides sp. & & pli & 2.2 \\
\hline Clypearia apicepennis & (Spinola, 1841) & cap & 3.2 & Protonectarina sylveirae & (Saussure, 1854) & prn & 2.7 \\
\hline Clypearia duckei & Richards, 1978 & $\mathrm{cdk}$ & 3.3 & Protopolybia chartergoides & (Gribbodo, 1891) & $\mathrm{pch}$ & 3.4 \\
\hline Clypearia sulcata & Saussure, 1854 & csu & 3.0 & Protopolybia duckeianus & (Richards, 1978) & pdk & 2.3 \\
\hline Clypearia weyrauchi & Richards, 1978 & cwe & 3.4 & Protopolybia emortualis & (Saussure, 1855) & pem & 2.2 \\
\hline Epipona media & Cooper, 2002 & epm & 2.4 & Protopolybia exigua & (Saussure, 1854) & pex & 2.6 \\
\hline Epipona tatua & Cuvier, 1797 & ept & 2.4 & Protopolybia fuscatus & (Fox, 1898) & $\mathrm{pfs}$ & 3.7 \\
\hline Leipomeles dorsata & (Fabricius, 1804) & lei & 2.2 & Protopolybia holoxantha & (Ducke, 1904) & phl & 2.8 \\
\hline Leipomeles pusilla & (Ducke, 1904) & & & Protopolybia nitida & (Ducke, 1904) & & \\
\hline Metapolybia cingulata & (Fabricius, 1804) & mci & 2.3 & Protopolybia sedula & (Saussure, 1854) & psd & 3.5 \\
\hline Metapolybia docilis & Richards, 1978 & mdl & 2.5 & Pseudopolybia compressa & (Saussure, 1854) & $\mathrm{cmp}$ & 2.0 \\
\hline Metapolybia nigra & Richards, 1978 & & & Pseudopolybia langi & Bequaert, 1944 & $\operatorname{lng}$ & 2.1 \\
\hline Metapolybia rufata & Richards, 1978 & mru & 2.5 & Pseudopolybia vespiceps & (Saussure, 1864) & vsp & 1.8 \\
\hline Metapolybia suffusa & (Fox, 1898) & & & Ropalidia cincta & (Lepeletier, 1836) & & \\
\hline Mischocyttarus adolphi & Zikán, 1949 & mdf & 2.1 & Ropalidia fasciata & (Fabricius, 1804) & & \\
\hline Mischocyttarus angulatus & Richards, 1945 & mng & 2.1 & Ropalidia grandidieri & (Saussure, 1890) & & \\
\hline Mischocyttarus cassununga & (Ihering, 1903) & $\mathrm{mss}$ & 2.1 & Ropalidia guttatipennis & (Saussure, 1853) & $\mathrm{rgt}$ & 2.1 \\
\hline Mischocyttarus cerberus & Ducke, 1918 & mcb & 2.4 & Ropalidia horni & Sonan, 1938 & rho & 2.2 \\
\hline Mischocyttarus collarelus & Richards, 1940 & mll & 2.2 & Ropalidia prasina & (Saussure, 1900) & $\mathrm{rpr}$ & 2.0 \\
\hline Mischocyttarus drewseni & Saussure, 1857 & $\mathrm{mdw}$ & 2.3 & Ropalidia sp. gr. malayana & (Cameron, 1903) & rey & 2.4 \\
\hline Mischocyttarus filliformis & (Saussure, 1854) & $\mathrm{mfl}$ & 2.0 & Ropalidia turneri & Richards, 1978 & rtu & 2.0 \\
\hline Mischocyttarus flavicans & (Fabricius, 1804) & mav & 2.4 & Synoeca cyanea & Fabricius, 1775 & scy & 2.6 \\
\hline Mischocyttarus flavitarsis & (Saussure, 1854) & mvt & 2.1 & Synoeca surinama & Linnaeus, 1767 & ssu & 2.7 \\
\hline Mischocyttarus injucundus & (Saussure, 1854) & mnj & 2.2 & Synoeca virginea & Fabricius, 1804 & svi & 2.5 \\
\hline Mischocyttarus latior & (Fox, 1898) & mlt & 2.0 & Provespa anomala & (Saussure, 1854) & & \\
\hline Mischocyttarus montei & Zikán, 1949 & $\mathrm{mmt}$ & 2.3 & Vespa analis & Fabricius, 1775 & & \\
\hline Mischocyttarus punctatus & (Ducke, 1904) & $\mathrm{mpc}$ & 2.1 & Vespa tropica & (Linnaeus, 1758) & $\mathrm{vpc}$ & 1.9 \\
\hline Mischocyttarus rotundicollis & Cameron, 1912 & $\mathrm{mrt}$ & 2.2 & Dolichovespula media & (Retzius, 1783) & vlm & 2.3 \\
\hline Mischocyttarus synoecus & Richards, 1940 & myn & 2.2 & Montezumia azurescens & (Spinola, 1851) & $\mathrm{mza}$ & 2.7 \\
\hline Nectarinella championi & (Dover, 1925) & & & Montezumia dimidiata & Saussure, 1852 & & \\
\hline Parachartergus fraternus & (Gribbodo, 1892) & $\mathrm{tft}$ & 2.0 & Zeta argillaceum & (Linnaeus, 1758) & zta & 3.6 \\
\hline
\end{tabular}

Revista Brasileira de Entomologia 55(4): 479-500, dezembro, 2011 